\title{
Importance of the Toxicological Tests in the Application and Safety of Ozone Therapy
}

\author{
Silvia Menendez-Cepero, Zullyt Zamora, Frank Hernandez \\ National Center for Scientific Research, Cuba
}

\section{O OPEN ACCESS}

\section{Citation}

Menendez-Cepero S, Zamora Z, Hernandez F. Importance of the Toxicological Tests in the Application and Safety of Ozone Therapy, J Ozone Ther. 2018:2(3)

doi: 10.7203/jo3t.2.3.2018.10009

\section{Academic Editor}

Jose Baeza-Noci,

School of Medicine, Valencia University, SPAIN

\section{Editor}

World Federation of Ozone Therapy, Bologna, ITALY

\section{Received}

March 22, 2017

\section{Accepted}

September 9, 2017

\section{Published}

December 15, 2018

\section{Intellectual Property}

Menendez-Cepero S.

This is an open access article distributed under the terms of the Creative Commons Attribution License (CC BY 4.0), which permits unrestricted use, distribution, and reproduction in any medium, provided the original author and source are credited.

\section{Author Information}

silviamenendez@infomed.sld.cu

\section{ABSTRACT}

Until today, there is not any official registry of the different routes of systemic ozone therapy. With the aim to prove the safety of this therapy, several ways of ozone $\left(\mathrm{O}_{3}\right)$ applications were evaluated, such as rectal insufflation (RI), major autohemotherapy (M-AHT) and intraperitoneal application (IP). For RI, some toxicological tests were performed such as: acute, sub-chronic, mutagenic (bone marrow chromosomic aberrations and micronucleus), teratogenic and irritation studies (at $40 \mathrm{mg} / \mathrm{L}$ and $10 \mathrm{~mL}$ during 15 days). For M-AHT, acute toxicological (in rats with 21, 47 and $64 \mathrm{mg} / \mathrm{L}$ and a volume of $2 \mathrm{~mL}$ with daily evaluation up to 15 days) and mutagenic (chromosomal aberration analysis, micronucleus assay and sister chromatid exchange test) studies were performed. For IP application, subchronic $\mathrm{O}_{3}$ was administered during 15 days in mice at concentrations of 11,29 and $35 \mathrm{mg} / \mathrm{L}$ and volumes of $80 \mathrm{~mL} / \mathrm{kg}$ ) and genotoxic (cytotoxic and clastogenic activity) studies were evaluated. All the toxicological studies performed for the $\mathrm{O}_{3} \mathrm{RI}$ fulfilled the requirements established for an official registry (no deleterious effects were observed). However, more toxicological studies must be done with respect to $\mathrm{M}-\mathrm{AHT}$ and IP $\mathrm{O}_{3}$ applications in order to prove the complete safety of these ways.

Keywords: Ozone therapy, toxicological studies, ozone rectal insufflation, ozone major autohemotherapy, ozone intraperitoneal application, National Health Regulatory Agencies.

\section{Introduction}

Ozone is a powerful oxidant, surpassed in this regard only by fluorine $[1,2]$ Its undoubtful strong reactivity has contributed to establish the dogma that ozone is always toxic and its medical application must be proscribed [3]. However, ozone therapy has been used for therapeutic purposes since the beginning of the last century [4-6] and their use is of an increase demand nowadays [7].

On the other hand, there are a number of good experimental studies showing that acute or chronic ozone inhalation damages the respiratory system and extrapulmonary organs [8-12]. But, there is now a reasonable understanding of several mechanisms of action and use of classical pharmacological concepts which make it possible to formulate a rationale for optimizing clinical applications and ways of ozone administration $[7,13]$.

Therefore, for proper enlightenment and guidance of the person interested in the use of ozone for medical purposes, becomes necessary scientific documentation on the safety/toxicity profile of these acclaimed procedure.

Among the required trials for an official registry of the different routes of 
parenteral systemic ozone therapy, preclinical toxicological tests are the first ones to be carried out. Until today, there is not any official registry of the different routes of parenteral systemic ozone therapy.

Taking into account that the National Health Regulatory Agencies require of documentation with scientific trials for sanitary registration of drugs and therapy procedures, different toxicological tests were performed in experimental animals, as well as two human trials, following the guidelines from the Cuban Regulatory Agency, Food Drug Administration, International Standards Organization and World Health Organization aimed at proving the safety of ozone therapy administration. According to the different toxicological tests, several ways of ozone applications were evaluated, such as rectal insufflation, major autohemotherapy and intraperitoneal application.

\section{Materials and methods}

For this study, it was used an OZOMED generator, constructed in Cuba by the Ozone Research Center.

\section{Experimental Animals [14-16]}

Sprague-Dawley Cenp:SPRD rats (male and female), Wistar rats (male and female), Mongolian Cenp:MERI gerbils (male and female), Syrio Cenp:AURA hamsters (male and female), B6D2F1 mice (male), Swiss albino mice (male), NMRI mice (male and female) and New Zealand rabbits (male and female) provided by from the National Center for Laboratory Animal Production (CENPALAB, Havana, Cuba) were employed for the studies. The body weight variation was within $\pm 20 \%$ of the mean weight in each sex. They were maintained under standard laboratory conditions all through the period of study and were fed on pelleted diet and given tap water ad libitum. Food and water were sterilized by autoclave. Animals were kept in wellventilated house conditions (room temperature range: $24 \pm 3{ }^{\circ} \mathrm{C}$; photoperiod: $12 \mathrm{~h}$ natural light and $12 \mathrm{~h}$ dark; humidity: $60 \pm 10 \%$ ). Experimental procedures were according to the Guidelines for Animal Experimentation as approved by the international, national and institutional guidelines for the Use and Care of Experimental Animals.

\section{Statistical Analysis}

Data were expressed as means \pm SD and subjected to one-way ANOVA using SPSS/PC-V 3.0 statistical software program followed by a homogeneity variance test (Bartlett-Box). Comparisons between two groups were performed (according to the different studies) by Student's t-test and the non-parametric tests: Kruskall-Wallis, Man Whitney and Wilconson. A value of $p<0.05$ was considered significantly different.

\section{1.- Toxicity studies}

\section{Bioassays}

For acute and sub-chronic studies blood samples for biochemical (alkaline phosphatase-ALP, alanine aminotransferase-ALT, aspartate aminotransferase-AST, total bilirubin, albumin, urea, creatinine, creatine phosphokinase, glucose, calcium, serum total protein, serum cholesterol and tryglycerides] and haematological (haemoglobin, hematocrit, lymphocytes, polymorphonuclear leukocyte) assays were performed.

\section{Histopathological studies}

The histopathology studies were done in: heart, lung, kidney, spleen, stomach, thymus, liver, ileum, colon, cecum, rectum, pancreas, testis, ovary and brain. The tissues were fixed in $10 \%$ formo-saline, dehydrated with $100 \%$ ethanol solution and embedded in paraffin. It was then processed 
into $4 \mu \mathrm{m}$ thick sections stained with haematoxylin-eosin and observed under a microscope.

\section{1.- Acute Toxicity Studies [17-19]}

1.1.1.- For evaluating acute toxicity of ozone by RI, two studies were performed:

A.- Sprague-Dawley Cenp:SPRD rats (100 to $120 \mathrm{~g}$ ), Mongolian Cenp:MERI gerbils $(70-80 \mathrm{~g})$ and Syrio Cenp:AURA hamsters (81 to $90 \mathrm{~g})$, males and females, were used. A total of 18 animals were divided in 6 groups ( 3 for sex of each rodent). It was used an ozone concentration of $75 \mathrm{mg} / \mathrm{L}$ and a volume of $8 \mathrm{~mL}$ for rats and $5 \mathrm{~mL}$ for the other rodents. The evaluation was made during the $72 \mathrm{~h}$ after the ozone $\mathrm{RI}$.

B.- Sprague-Dawley Cenp:SPRD rats (100 to $120 \mathrm{~g}$ ) of both sexes were used. A total of 50 animals were divided in 5 experimental groups, of 10 animals each ( 5 animals per sex):

1- control treated with air.

2- control treated with oxygen.

3- treated with ozone at a concentration of $25 \mathrm{mg} / \mathrm{L}$.

4- treated with ozone at a concentration of $50 \mathrm{mg} / \mathrm{L}$.

5- treated with ozone at a concentration of $75 \mathrm{mg} / \mathrm{L}$.

The gas volume was of $5 \mathrm{~mL}$ for each group. The study lasted 14 days after the single application of ozone by $\mathrm{RI}$.

For the $\mathrm{Rl}$ procedures it was used a stainless steel cannula (external diameter $\sim 1 \mathrm{~mm}, 4 \mathrm{~cm}$ length) which was introduced $2 \mathrm{~cm}$ inside the rectum. It was made always at the same hour (9 am).

\subsection{2.- Acute toxicity test of ozone by M-AHT:}

Sixty four Sprague-Dawley Cenp:SPRD rats (32 of each sex), between 151 and $200 \mathrm{~g}$ weight were divided in 4 experimental groups of 16 animals each (8 animals per sex):

1- control treated with oxygen.

2- treated with ozone at a concentration of $21 \mathrm{mg} / \mathrm{L}$.

3- treated with ozone at a concentration of $47 \mathrm{mg} / \mathrm{L}$.

4- treated with ozone at a concentration of $64 \mathrm{mg} / \mathrm{L}$.

The gas volume was of $2 \mathrm{~mL}$ for each group. The study lasted 14 days after the single application of ozone or oxygen by M-AHT.

For the M-AHT procedure, each animal was extracted $2 \mathrm{~mL}$ of blood from the orbital plexus, using a Pasteur pipette previously impregnated, inside, of an anticoagulant solution (sodium citrate $3.8 \%$ ). This blood was poured in a sterile flask containing the anticoagulant in a proportion of 1 volume of this anticoagulant/ 9 volumes of blood. Then, it was slowly bubbled $2 \mathrm{~mL}$ of ozone inside the blood and gentle mixed avoiding foaming and haemolysis. Afterwards, this ozonized blood was reinfused by intravenous way using the tail vein. For the control it was used oxygen instead of ozone.

\section{2.- Sub-Chronic Toxicity Studies [17-19]}

\subsection{1.- For evaluating sub-chronic toxicity of ozone by RI, two studies were performed:}

A.- Sprague-Dawley Cenp:SPRD rats (160-220 g) of both sexes were divided in 5 experimental groups, of 40 animals each (20 animals per sex) for the control and ozone groups and 20 animals (10 animals per sex) for the sentinel group:

1- treated with ozone at lower doses $(160 \mu \mathrm{g} / \mathrm{kg}$ and $4 \mathrm{~mL} / \mathrm{kg})$. 
2- treated with ozone at medium doses $(400 \mu \mathrm{g} / \mathrm{kg}$ and $10 \mathrm{~mL} / \mathrm{kg})$.

3 - treated with ozone at higher doses $(1000 \mu \mathrm{g} / \mathrm{kg}$ and $25 \mathrm{~mL} / \mathrm{kg})$.

4- control, treated with oxygen $(25 \mathrm{ml} / \mathrm{kg})$.

5- sentinel group-rats treated with the higher ozone dose, but at the end of the treatment were maintained alive during a month for their evaluation.

The ozone concentration was $40 \mathrm{mg} / \mathrm{L}$. The ozone was applied during 28 days ( 6 days per week).

B.- New Zealand rabbits $(\sim 2 \mathrm{~kg})$ of both sexes were divided in 4 experimental groups, of 10 animals each ( 5 animals per sex), except for the group with the high ozone doses that comprised 6 animals more:

1- control, treated with oxygen.

2- treated with ozone at low dose $(286 \mu \mathrm{g} / \mathrm{kg})$.

3- treated with ozone at medium dose $(669 \mu \mathrm{g} / \mathrm{kg})$.

4- treated with ozone at high dose $(1209 \mu \mathrm{g} / \mathrm{kg})$.

The ozone concentrations were 20,35 and $52 \mathrm{mg} / \mathrm{L}$ with volumes of 30,40 and $50 \mathrm{~mL}$, respectively, during 90 days (3 days per week). The 6 animals added to group 4 were not sacrificed at the end of the ozone treatment, they were kept alive for further 21 days in order to observe the reversibility of the possible side effects present in the study.

\subsection{2.- Sub-chronic toxicity of ozone by IP application:}

Forty B6D2F1 mice $(18-20 \mathrm{~g})$, male, were divided in four groups of 10 animals each:

1- control, treated with oxygen.

2- treated with ozone at $11 \mathrm{mg} / \mathrm{L}$.

3- treated with ozone at $29 \mathrm{mg} / \mathrm{L}$.

4- treated with ozone at $35 \mathrm{mg} / \mathrm{L}$.

In all the groups a volume of $80 \mathrm{~mL} / \mathrm{kg}$ was used. The treatment was of 15 sessions, one daily.

In all animals of both studies (acute and subchronic) were observed daily toxicity signs as: fur aspect and its loss, state of the eyes, mucosa and site of the ozone application, general state, behaviour patterns, coma, lethargy, sleepeness, tremor, motor activity, presence of convulsions, death, diarrhea, salivation and circulatory, respiratory and nervous central systems.

During the study, body weights were monitored according to the experimental design (at the beginning, weekly and at the end of the treatment) and the mean values recorded, as well as water and food consumption.

After $24 \mathrm{~h}$ of completion of the study, animals were euthanized by cervical dislocation and subjected to a gross necropsy and histopathology observation for toxicity. Before the sacrifice they were narcotized under diethyl ether anaesthesia and bled to death by the femoral vein (animals were fasted $24 \mathrm{~h}$ before the blood samples for bioassays were obtained).

\section{2.- Rectal irritation study [20]}

Nine New Zealand rabbits $(>2 \mathrm{~kg}$ ), males, were divided at random in 3 groups of 3 animals each:

1 - control, treated with oxygen $(10 \mathrm{~mL})$.

2- placebo, treated with saline solution $(10 \mathrm{ml} \mathrm{NaCl} 0.9 \%)$.

3- ozone, treated with an ozone concentration of $40 \mathrm{mg} / \mathrm{L}$ and a volume of $10 \mathrm{~mL}$.

Ozone, oxygen and saline solution were applied by rectal application during 15 days ( 6 days per week), every day at $8 \mathrm{am}$, using stainless steel cannulas which were introduced in the rectum $(\sim 7 \mathrm{~cm})$. 
Before and after each session of treatment, the perineum appearance was observed in order to evaluate any signs of secretion, erythema, irritation, bleeding or diarrhea. Also, the body weight was monitored, as well as any other abnormal clinical sign, as an evidence of a possible systemic side effect.

After $24 \mathrm{~h}$ of termination of the study, animals were euthanized by cervical

Table 1. Irritation index (X) classification

\begin{tabular}{cc}
\hline Result & Classification \\
\hline 0 & No irritation \\
$1 \leq X<5$ & minimum \\
$5 \leq X<9$ & medium \\
$9 \leq X<12$ & moderate \\
$12 \leq X 16$ & severe \\
\hline
\end{tabular}

dislocation and subjected to histopathology observation of the anus and $10 \mathrm{~cm}$ of rectum, looking for toxicity. First, it was observed if there was the presence of some irritation, epithelium damage or necrosis. Then, all the parts were well clean and fixed in 10\% formo-saline, dehydrated with $100 \%$ ethanol solution and embedded in paraffin for the histological exam. Three sections were studied: proximal, medial and distal. It was calculated an irritation index $(X)$ for each experimental group and its classification was taken into account according to the values referred in Table 1.

\section{3.- Mutagenesis assay [21-23]}

3.1.- For the study of the ozone mutagenic effect by RI, two studies were performed evaluating its ability to induce micronuclei in the bone marrow of Sprague-Dawley rats and NMRI mice [24-26]

A.- Sprague-Dawley Cenp:SPRD rats (180-220 g) of both sexes were divided in 4 experimental groups, of 10 animals each ( 5 animals per sex):

1- negative control, treated with $5 \mathrm{~mL}$ of oxygen.

2- treated with ozone at an ozone concentration of $50 \mathrm{mg} / \mathrm{L}$ and $5 \mathrm{~mL}(1250$ $\mu \mathrm{g} / \mathrm{kg}$ ).

3- treated with ozone at an ozone concentration of $75 \mathrm{mg} / \mathrm{L}$ and $5 \mathrm{~mL}$ (1875 $\mu \mathrm{g} / \mathrm{kg})$.

4- positive control, treated with cyclophosphamide by IP way $(40 \mathrm{mg} / \mathrm{kg}$ weight).

Only one administration (ozone, oxygen or cyclophosphamide) was studied.

B.- NMRI mice (27-35 g) of both sexes were divided in 4 experimental groups, of 10 animals each ( 5 animals per sex):

1- negative control, treated with $2 \mathrm{~mL}$ of oxygen.

2- treated with ozone at an ozone concentration of $50 \mathrm{mg} / \mathrm{L}$ and $2 \mathrm{~mL}$ (3333 $\mu \mathrm{g} / \mathrm{kg}$;

3- treated with ozone at an ozone concentration of $75 \mathrm{mg} / \mathrm{L}$ and $2 \mathrm{~mL}(5000$ $\mu \mathrm{g} / \mathrm{kg}$ );

4- positive control, treated with cyclophosphamide by IP way $(40 \mathrm{mg} / \mathrm{kg}$ weight).

Only one administration (ozone, oxygen or cyclophosphamide) was studied.

All the animals were euthanized $24 \mathrm{~h}$ after the treatment by atloaxoid 
dislocation. Two hours before the sacrifice, all animals were administered colchicine (4 mg/kg weight) by IP way. Both femurs of all animals were extracted and the bone marrow was collected in fetal bovine serum (FBS). This liquid phase was centrifugated between 800 and $1000 \mathrm{rpm}$ during $5 \mathrm{~min}$. The supernatant was eliminated and the cells were resuspended in $50 \mathrm{~mL}$ of FBS. Two smears per animal were done. After drying them by air, they were fixed with methanol for 5 min. Twenty four hours later they were stained with Giemsa 5\% (Sigma) for $15 \mathrm{~min}$. Giemsa was poured off and visible cells were counted.

Bone marrow cells from animals were analyzed for the number of polychromatic erythrocytes (PCE) that contained at least one micronucleus. A minimum of 1000 PCEs per animal was analyzed for each group in order to determine the percentages of micronucleus (using an Olympus microscope at a 100x magnification). For the citotoxicity index (PCE/NCEnormochromatic erythrocytes), 500 cells per animal were counted.

3.2.- For the study of the genotoxic effect of ozone in human leukocytes in vitro, the single cell gel electrophoresis (SCGE) assay [27] with minor modifications [28] was used

Peripheral blood was obtained from six healthy, non-smoking volunteers, aged 22-48 years. The blood was diluted in phosphate buffer solution (PBS), $60 \mu \mathrm{L}$ blood in $1 \mathrm{~mL}$ PBS, and drawn into a $10 \mathrm{~mL}$ syringe. The ozone was introduced into the syringe, which was incubated while gently shaking for $1 \mathrm{~h}$ at $37{ }^{\circ} \mathrm{C}$. The ozone concentration ranged from 20 to $50 \mu \mathrm{g} /$ $\mathrm{ml}$ with a volume of $1 \mathrm{ml}$. Whole blood and blood diluted in PBS were used as non-treated controls. To asses post-treatment recovery, cells from 4 donors treated with the highest ozone dose $(5.25 \mathrm{mM})$ were centrifugated, resuspended in fresh PBS and incubated for 45 and 90 min after treatment. The slides were observed under fluorescence microscope with a calibrated ocular micrometer. Images of 50 randomly selected cells $(25$ cells from each 2 replicate slides) were analyzed from each treatment. From each cell, the length of the image (diameter of the nucleus plus migrated DNA) was measured in microns at a 400x magnification. Also, the effect of catalase was studied by pre-incubating the dilute blood from the other 2 donors with catalase $(20 \mu \mathrm{g} / \mathrm{mL})$ for $15 \mathrm{~min}$ before $\mathrm{O}_{3}$ treatment as above.

\section{3.- Genotoxic effect of ozone in patients treated with ozone by M-AHT, measuring chromosomal aberrations, frequency of sister chromatid exchange and mycronucleus test}

Twenty one patients suffering from various diseases (Retinitis Pigmentosa, senile dementia, arthrosis, glaucoma, arterial insufficiency) were involved in this study. Ozone was administered by M-AHT (200 mL of blood are drawn and then are bubbled with $100 \mathrm{~mL}$ of ozone at a concentration of $50 \mathrm{mg} / \mathrm{L}$ ), daily (5 days per week), during 3 weeks.

For Chromosomal Aberrations Analysis (CA), $1 \mathrm{~mL}$ of heparinized blood was added to $8 \mathrm{~mL}$ of RPMI culture medium, supplied with $1 \mathrm{~mL}$ of fetal bovine serum $20 \%, 400 U$ of penicillin and phytohemagglutinin $(180 \mu \mathrm{g} / \mathrm{mL})$. Cells were grown for $47 \mathrm{~h}$ and $30 \mathrm{~min}$, then expose to colchicines for $30 \mathrm{~min}$. Fixation was done [29], modified in our laboratory. One hundred cells were spread and stained metaphases were analyzed at 1000x.

For Sister Chromatid Exchanges (SCE), the procedure for cell culture was similar to that in CA, but here cells were cultured in a media containing 5bromo-2-deoxiuridine $(10 \mathrm{mg} / \mathrm{mL})$. Slides were treated to achieve sister chromatid differentiation, after fluorescence plus Giemsa technique [30]. Forty metaphases were analyzed at 1000x. SCE means were calculated dividing the total number of exchanges by the total number of cells scored in a subject. 
For micronucleus test, cells were cultured in the same ways as previously explained, but after $44 \mathrm{~h}$ cytochalasin B was added $3 \mathrm{mg} / \mathrm{mL}$ ). Incubation was interrupted at $72 \mathrm{~h}$ and cells were processed as described by Fenech and Morley [31]. Five hundred binucleated cells were scored at 40x.

\section{4.- Ozone mutagenic effect by IP application}

Swiss albino mice (25-30 g), males, were divided in 5 experimental groups of 6 animals each:

1- control, treated with oxygen using $1 \mathrm{~mL}$.

2- treated with $1 \mathrm{~mL}$ of ozone $(2333 \mu \mathrm{g} / \mathrm{kg})$.

3- treated with $0.7 \mathrm{~mL}$ of ozone $(1633 \mu \mathrm{g} / \mathrm{kg})$.

4- treated with $0.4 \mathrm{~mL}$ of ozone $(933 \mu \mathrm{g} / \mathrm{kg})$.

5 - treated with $0.2 \mathrm{~mL}$ of ozone $(466 \mu \mathrm{g} / \mathrm{kg})$.

The ozone concentration was $70 \mu \mathrm{g} / \mathrm{mL}$ and it was applied daily during 15 days.

The process for the extraction of the bone marrow was the same as explained above. It was processed 3 slides per animal and 6 animals per group for the analysis of chromosomal aberrations, mitotic index, number of gaps and breakage.

\section{4.- Teratogenic assay}

For the study of the ozone teratogenic effect in animals treated by Rl, Wistar rats (200-250 g), females, were divided in 3 experimental groups:

1 - control $(n=15)$, without any treatment.

2- treated with $1 \mathrm{~mL}$ of ozone $(\mathrm{n}=17)$ at a concentration of $34 \mu \mathrm{g} / \mathrm{mL}$ (150 $\mathrm{\mu g} / \mathrm{kg})$.

3- treated with $4 \mathrm{~mL}$ of ozone $(\mathrm{n}=17)$ at a concentration of $90 \mu \mathrm{g} / \mathrm{mL}$ $(1600 \mu \mathrm{g} / \mathrm{kg})$.

Ozone was administered by RI during 10 sessions, from the 6th to the 15 th day of gestation.

Females and males were mated in a relation 2:1. The pregnancy was confirmed by the presence of spermatozoa in the vaginal exudates. It was considered that the animals with positive exudates were in the 0 day of gestation.

In the 19th day of gestation, animals were euthanized by an ether overdose and the fetus were obtained by cesarean. It was registered the number of: corpus luteum, implantations, alive and dead fetus, reabsorptions, as well as the weight and the length cranium-caudal of each fetus. Alive fetus were examined to find any external malformations. Defective viscera were evaluated by Wilson technique [32], in approximately half of the animals. The rest of the fetus were stained with alizarin for the skeleton exam [33]. Died fetus were included in the group of reabsorptions.

\section{Results}

\section{1.- Toxicity studies}

\section{1.- Acute Toxicity Studies}

\subsection{1.- Ozone by Rl:}

It was observed that all the animals treated with ozone by $\mathrm{RI}$ were normal. Daily cage-side observations did not reveal any physical changes or toxic symptoms in clinical observations in the skin, fur, eyes, respiratory system and general behavioural patterns. Normal consumption of water and food were observed. 
In study A (where were evaluated 3 different rodents, $72 \mathrm{~h}$ after the ozone $\mathrm{RI}$ ), the histological study of rectum, heart, liver and encephalon demonstrated that the application of ozone by RI did not produce any damages in rectum mucosa or in the other organs studied.

In study B (where were evaluated in rats, 3 different ozone concentrations, lasting 14 days after the ozone RI), the mean weight behaviour for females and males, during these 14 days, is observed in Figure 1 and 2, respectively.

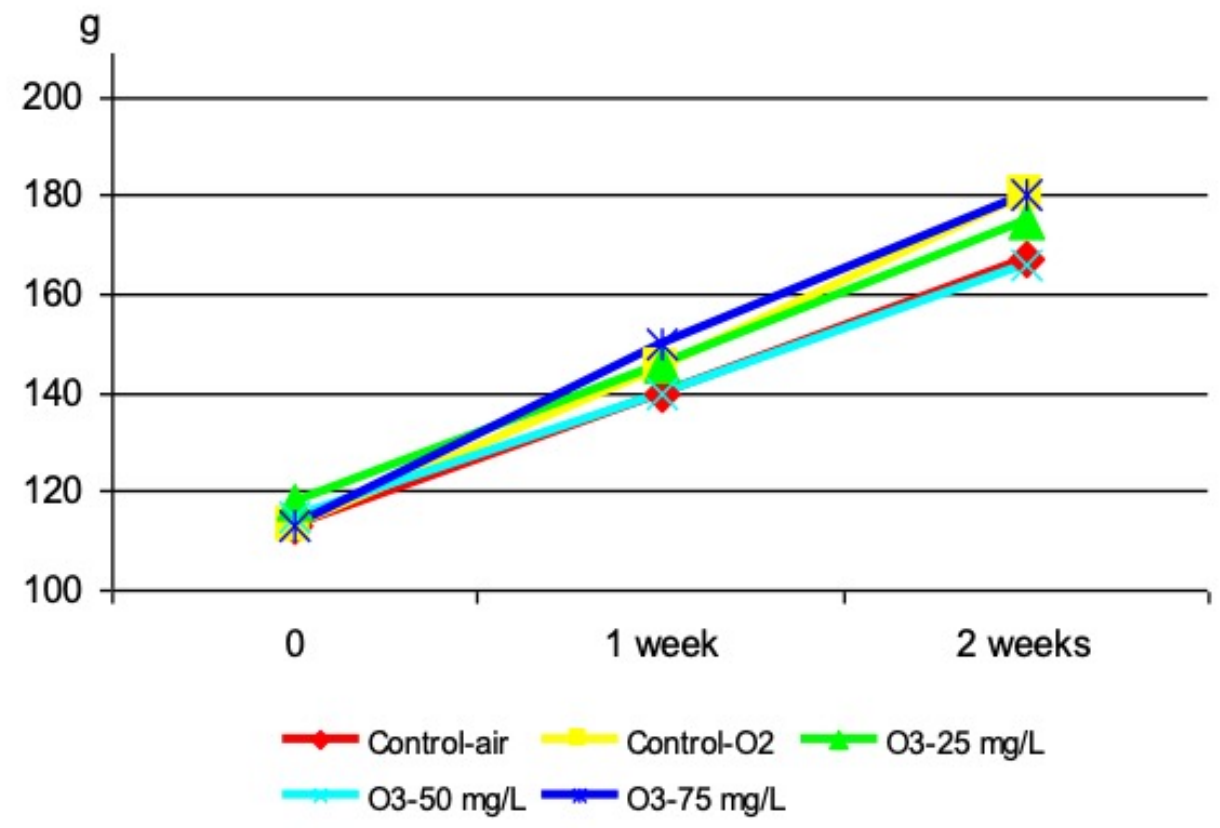

Figure 1. Mean weight behaviour for females.

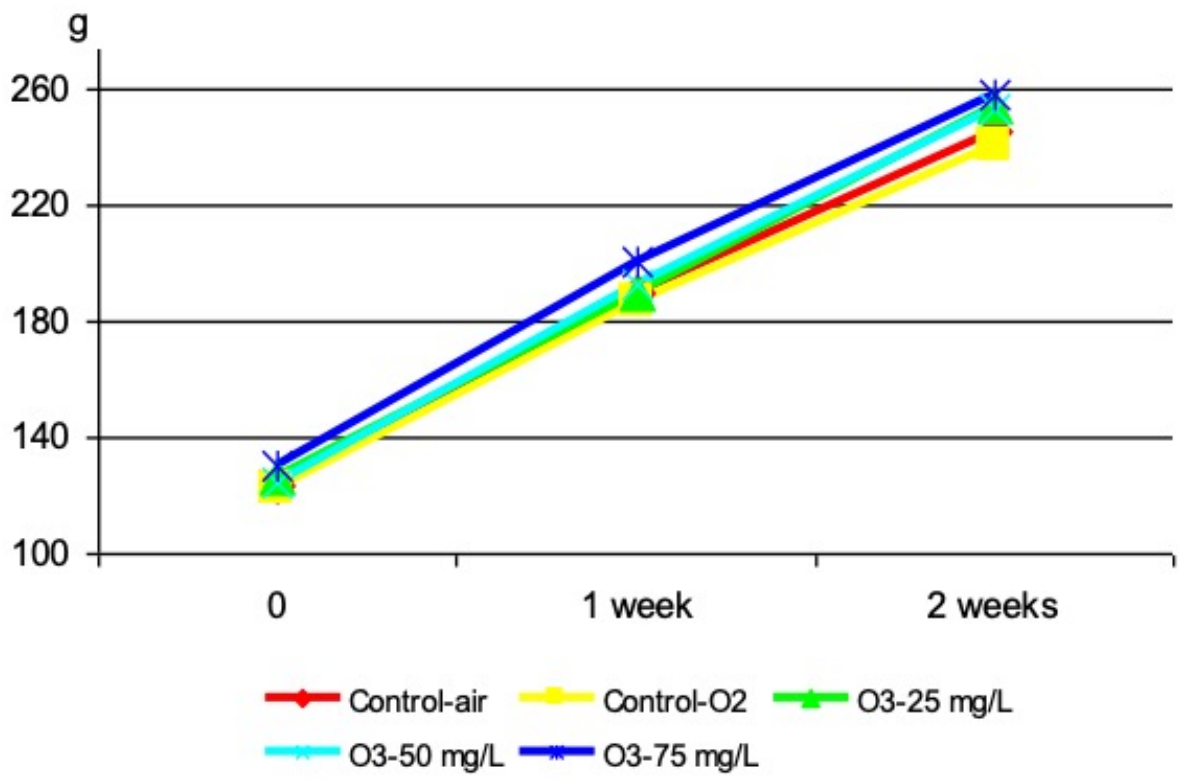

Figure 2. Mean weight behaviour for males. 
Males and females increased gradually their body weight, since the first day of the study up to the 14th day (end of the study), with a greater increase in males. No significant differences were observed among the different groups $(p>0.05)$. This uniform behaviour in the body weight increase in all the groups and sexes indicates that there is no evidence of side effects in this indicator due to the ozone RI.

The growth and development of animals is the resultant of a complex process that involves several genetic, physiological and biochemical mechanisms, as well as external factors also very diverse. Among these external factors, the main role is feeding and water consumption. However, in rats it has to be also considered the coprophagy that can favour the weight loss due to nutritive alterations. In this study, coprophagy was eliminated using cages with a bottom grille and a tray. Therefore, the analysis of the body weight fluctuations is an objective index of possible side effects of the substance in study and it is considered one of the most significant indexes to evaluate toxicity [34].

With respect to consumption of water, no significant differences were observed among the groups within one sex. However, some differences between male and females were observed. Males had less consumption of water during the study than females. The trend of the mean water consumption values is to diminish with the increase of age and in our study was similar for both sexes $(p>0.05)$. This behaviour is in correspondence with literature [35].

According to food consumption, the results were similar to water consumption. Males had more food consumption in comparison with females, but the trend was similar for both sexes ( $>0.05)$. Also, a trend to decrease with respect to time was observed, as referred in literature [35].

For the hematological study, performed in the 14th day after the ozone RI, only the higher ozone concentration $(75 \mathrm{mg} / \mathrm{L})$ was considered. The results of the different biochemical parameters measured are shown in Table 2.

Table 2. Behavior of the different biochemical parameters measured in rats treated with ozone by RI at a concentration of $75 \mathrm{mg} / \mathrm{L}$

\begin{tabular}{|c|c|c|c|c|}
\hline \multirow{3}{*}{$\begin{array}{l}\text { Biochemical parameter } \\
\text { Hematocrit (\%) }\end{array}$} & \multicolumn{2}{|c|}{ Females } & \multicolumn{2}{|c|}{ Males } \\
\hline & Control & $\mathrm{O}_{3}(75 \mathrm{mg} / \mathrm{L})$ & \multicolumn{2}{|c|}{ Control $\quad \mathrm{O}_{3}(75 \mathrm{mg} / \mathrm{L})$} \\
\hline & $48.75 \pm 11.44$ & $50.25 \pm 2.87$ & $50.6 \pm 5.37$ & $49.33 \pm 17.5$ \\
\hline Calcium (mmol/L) & $2.66 \pm 0.36$ & $2.8 \pm 0.16$ & $2.75 \pm 0.28$ & $2.98 \pm 0.19$ \\
\hline Albumin (g/dL) & $3.1 \pm 0.54$ & $3.28 \pm 0.17$ & $3.02 \pm 0.42$ & $3.18 \pm 0.21$ \\
\hline Total protein $(\mathrm{g} / \mathrm{dL})$ & $6.33 \pm 0.99$ & $6.65 \pm 0.39$ & $6.58 \pm 0.74$ & $6.7 \pm 0.4$ \\
\hline ALT (U/L) & $52.5 \pm 8.43$ & $56 \pm 11$ & $53.6 \pm 22.1$ & $51 \pm 4$ \\
\hline Cholesterol (mg/dL) & $62.25 \pm 12.37$ & $77 \pm 22$ & $94.6 \pm 30.7$ & $68.5 \pm 17.8$ \\
\hline Triglycerides (mg/dL) & $109 \pm 22$ & $104 \pm 7$ & $119 \pm 18$ & $95.8 \pm 14.1$ \\
\hline AST (U/L) & $143 \pm 75$ & $136 \pm 24$ & $132 \pm 21$ & $126 \pm 33$ \\
\hline Alkaline phosphatase (U/L) & $283 \pm 57$ & $329 \pm 68$ & $412.4 \pm 64.1$ & $451 \pm 71$ \\
\hline Creatinin phosphatase (U/L) & $2498 \pm 951$ & $2362 \pm 1017$ & $2459 \pm 1090$ & $1627 \pm 759$ \\
\hline
\end{tabular}

ALT-Alanine aminotransferase; AST-Aspartate aminotransferase. 
No significant differences were found between the groups for all the biochemical parameters studied ( $p>0.05$ ). In general, in the male group the values were greater in comparison with females, similar to other studies [36]. Therefore, one application of ozone (at the highest concentration) by RI, to female and male rats, did not affect the biomarkers of specific damages to different organs.

With respect to the histological study (performed also in the 14th day after the ozone RI) any evidence of damage in the digestive system or in the other organs studied, associated to the administration of ozone by $\mathrm{Rl}$, was observed. The effect of ozone on weights of some vital body organs, in female and male rats, showed no significant difference in the organ weight in both, treated with the highest ozone concentration and control groups (Table 3).

Table 3. Comparison of the weight of different organs between the ozone group (at the highest concentration) and the control treated with air for both sexes.

\begin{tabular}{lcccc}
\hline Organs & \multicolumn{2}{c}{$\begin{array}{c}\text { Female weight }(\mathrm{g}) \\
\text { Control }\end{array}$} & $\mathrm{O}_{3}(75 \mathrm{mg} / \mathrm{L})$ & \multicolumn{2}{c}{ Male weight $(\mathrm{g})$} \\
& Control & $\mathrm{O}_{3}(75 \mathrm{mg} / \mathrm{L})$ \\
\hline Thymus & $0.53 \pm 0.07$ & $0.59 \pm 0.08$ & $0.69 \pm 0.06$ & $0.74 \pm 0.10$ \\
Spleen & $0.50 \pm 0.07$ & $0.54 \pm 0.10$ & $0.78 \pm 0.15$ & $0.71 \pm 0.12$ \\
Heart & $0.77 \pm 0.07$ & $0.88 \pm 0.11$ & $1.06 \pm 0.11$ & $0.99 \pm 0.06$ \\
Encephalon & $1.67 \pm 0.04$ & $1.76 \pm 0.11$ & $1.76 \pm 0.06$ & $1.83 \pm 0.04$ \\
Liver & $8.49 \pm 1.24$ & $9.27 \pm 1.02$ & $12.16 \pm 2.04$ & $10.76 \pm 2.11$ \\
\hline
\end{tabular}

It has to be done separately in females and males because the sex significantly influences in the weight of the body organs. All these results indicate the absence of toxic effects due to one application of ozone by RI at doses.

\subsection{2.- Ozone by M-AHT:}

Similar results to ozone by $\mathrm{RI}$ were obtained It was observed that all the animals treated with ozone by M-AHT were normal. Daily cage-side observations did not reveal any physical changes or toxic symptoms in clinical observations in the skin, fur, eyes, respiratory system and general behavioural patterns. Special attention was taken into account in the site of ozone infusion, looking for signs of inflammation, necrosis or irritation. Normal consumption of water and food were observed.

According to the behaviour of the body weight, males and females increased gradually their weight, since the first day of the study up to the 14th day (end of the study), with a greater increase in males. No significant differences ( $>0.05$ ) were observed among the different groups (Table 4). These results indicate that there is no evidence of side effects in this indicator due to the application of ozone by M-AHT.

The histological study of lung, heart, liver, kidneys, spleen and encephalon demonstrated that the application of ozone by M-AHT did not produce any damages in the organs studied. It can be concluded that the application of ozone by M-AHT did not produce any toxicity in rats. 
Table 4. Behavior of the body weight (g) in the different groups, in respect to each sex and the days which it was measured.

\begin{tabular}{ccccccccc}
\hline Days & \multicolumn{2}{c}{ Control $\left(\mathrm{O}_{2}\right)$} & \multicolumn{2}{c}{ Ozone $(21 \mathrm{mg} / \mathrm{L})$} & \multicolumn{2}{c}{ Ozone $(47 \mathrm{mg} / \mathrm{L})$} & \multicolumn{2}{c}{ Ozone $(64 \mathrm{mg} / \mathrm{L})$} \\
& Female & Male & Female & Male & \multicolumn{2}{c}{ Female } & Male & \multicolumn{2}{c}{ Female } & Male \\
\hline 0 & $197 \pm 12$ & $267 \pm 13$ & $194 \pm 11$ & $263 \pm 13$ & $198 \pm 13$ & $263 \pm 13$ & $194 \pm 7$ & $269 \pm 8$ \\
7 & $220 \pm 12$ & $312 \pm 7$ & $222 \pm 9$ & $312 \pm 19$ & $233 \pm 15$ & $298 \pm 19$ & $222 \pm 14$ & $320 \pm 12$ \\
14 & $230 \pm 14$ & $340 \pm 4$ & $243 \pm 10$ & $321 \pm 34$ & $248 \pm 17$ & $322 \pm 27$ & $237 \pm 12$ & $353 \pm 11$ \\
\hline
\end{tabular}

\section{2.- Sub-Chronic Toxicity Studies}

\subsection{1.- Ozone by Rl:}

A.- The results of the sub-chronic toxicity of ozone by RI, performed in rats during 28 days, showed no toxic signs or symptoms related to the ozone application. All animals were normal. As in the acute toxicity study, daily cage-side observations did not reveal any physical changes or toxic symptoms in clinical observations.

The variation of the body weight is one of the main parameters, indicative of systemic toxicity. Both sexes increased gradually their weight, since the first day of the study up to the 28th day (end of the study), with a greater increase in males. No significant differences ( $p>0.05)$ were observed among the different groups (Table 5). Also, when it is compared the mean weight gained at the end of the treatment, no significant differences were observed among the different groups. This is an evidence of the absence of toxic effects associated to the ozone treatment.

Table 5. Behavior of the body weight (g) in the different groups (performed by rectal insufflation), in respect to each sex and the weeks which it was measured.

\begin{tabular}{|c|c|c|c|c|c|c|c|c|}
\hline \multirow{3}{*}{$\begin{array}{r}\text { Weeks } \\
0\end{array}$} & \multicolumn{2}{|c|}{ Control $\left(\mathrm{O}_{2}\right)$} & \multicolumn{2}{|c|}{ Ozone $(160 \mu \mathrm{g} / \mathrm{kg})$} & \multicolumn{2}{|c|}{ Ozone $(400 \mu \mathrm{g} / \mathrm{kg})$} & \multirow{2}{*}{\multicolumn{2}{|c|}{$\begin{array}{l}\text { Ozone }(1000 \mu \mathrm{g} / \mathrm{kg}) \text { Female } \\
\text { Male }\end{array}$}} \\
\hline & Female & Male & Female & Male & Female & Male & & \\
\hline & $211 \pm 18$ & $232 \pm 16$ & $202 \pm 5$ & $239 \pm 13$ & $173 \pm 11$ & $168 \pm 10$ & $163 \pm 13$ & $189 \pm 15$ \\
\hline 1 & $224 \pm 19$ & $261 \pm 17$ & $213 \pm 6$ & $261 \pm 12$ & $201 \pm 11$ & $235 \pm 10$ & $192 \pm 13$ & $226 \pm 17$ \\
\hline 2 & $239 \pm 16$ & $273 \pm 27$ & $226 \pm 9$ & $267 \pm 17$ & $225 \pm 11$ & $265 \pm 11$ & $221 \pm 11$ & $259 \pm 19$ \\
\hline 3 & $253 \pm 22$ & $308 \pm 36$ & $242 \pm 9$ & $294 \pm 24$ & $235 \pm 13$ & $274 \pm 12$ & $231 \pm 11$ & $272 \pm 21$ \\
\hline 4 & $255 \pm 22$ & $335 \pm 32$ & $237 \pm 11$ & $313 \pm 31$ & $238 \pm 16$ & $301 \pm 15$ & $244 \pm 12$ & $302 \pm 31$ \\
\hline
\end{tabular}

The hematological responses of rats submitted to 28 days of ozone by $\mathrm{RI}$ demonstrated no significant effects ( $p>0.05$ ) on hemoglobin and hematocrit, all the values were within the physiological range in the evaluations performed on day 7th and 28th (Table 6). However, with respect to haemoglobin, significant increases were observed in the ozone groups, at medium and high doses, with respect to control at day 7th, but at day 28th no significant differences were observed among the groups. Lymphocytes, at day 7 th, in ozone at medium and high doses, had significant lower values with respect to control group even under the physiological range. However, at day 28th, all the groups were within the physiological range, indicating a process of adaptation in response to treatment. Neutrofils showed decreased values in control and ozone at low dose, at day 7th, with respect to the other groups, even below the physiological range. At day 28th, all the 
groups had values below the physiological range, even the sentinel group. That is the reason why it is not related to the ozone treatment (Table 6). Monocyte values were within the physiological range in all the groups and no significant differences were observed among them.

Changes in alkaline phosphatase, alanine aminotransferase (ALT), aspartate aminotransferase (AST) and serum proteins can suggest hepatitic toxicity. Alkaline phosphatase values were within the physiological range, with no significant differences among groups. (Table 7).

Aminotransferases (ALT and AST) increase their values when tissue damages are present, being these enzymes released to blood circulation. ALT values were all within the physiological range, but the high ozone dose had significant increase values with respect to the other groups. However, at day 28th all the values remained within the physiological range without significant differences among them. This means a reversibility of the effect. With respect to AST, at day 7th, the groups of low ozone dose and control presented significant decreased values in comparison with the other groups, even below the physiological range. At day 28th, the group of low ozone dose remained below the physiological range, with significant differences with respect to control group. However, in the analysis of the sentinel group, it can be seen that one month after the end of the treatment, its value was in the physiological range. Also, the decrease in the levels of AST and ALT is not associated with any organic damage. Total proteins presented, in all the groups (except for the low ozone dose at day 7th), values below the

Table 6. Hematological responses of rats submitted to 28 days of ozone by rectal insufflation.

\begin{tabular}{ccccccccc}
\hline & \multicolumn{2}{c}{ Hemoglobin (g/dL) } & \multicolumn{2}{c}{ Hematocrit (L/L) } & \multicolumn{2}{c}{ Lymphocytes (x109/L) } & \multicolumn{2}{c}{ Neutrophil (x109/L) } \\
G & Day 7 & Day 28 & Day 7 & Day 28 & Day 7 & Day 28 & Day 7 & Day 28 \\
\hline 1 & $12.7 \pm 0.7^{\mathrm{a}}$ & $13.8 \pm 1.4$ & $0.43 \pm 0.02$ & $0.43 \pm 0.03$ & $7.27 \pm 0.03^{\mathrm{a}}$ & $7.26 \pm 0.06$ & $0.23 \pm 0.03^{\mathrm{a}}$ & $0.24 \pm 0.06$ \\
2 & $13.8 \pm 0.8^{\mathrm{b}}$ & $13.4 \pm 3.1$ & $0.42 \pm 0.02$ & $0.42 \pm 0.02$ & $4.76 \pm 0.09 \mathrm{~b}$ & $7.84 \pm 0.05$ & $0.46 \pm 0.08^{\mathrm{b}}$ & $0.21 \pm 0.05$ \\
3 & $13.8 \pm 0.8^{\mathrm{b}}$ & $13.6 \pm 0.8$ & $0.42 \pm 0.02$ & $0.42 \pm 0.02$ & $4.80 \pm 0.06^{\mathrm{b}}$ & $7.41 \pm 0.06$ & $0.44 \pm 0.06^{\mathrm{b}}$ & $0.22 \pm 0.05$ \\
4 & $12.8 \pm 0.8^{\mathrm{a}}$ & $13.0 \pm 0.6$ & $0.43 \pm 0.02$ & $0.43 \pm 0.03$ & $7.24 \pm 0.09 \mathrm{a}$ & $7.61 \pm 0.06$ & $0.24 \pm 0.10^{\mathrm{a}}$ & $0.26 \pm 0.07$ \\
$\mathrm{~S}$ & - & $13.8 \pm 0.9$ & - & $0.43 \pm 0.02$ & - & $7.81 \pm 0.45$ & - & $0.18 \pm 0.05$ \\
\hline
\end{tabular}

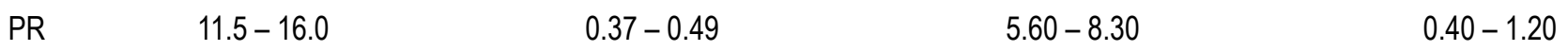

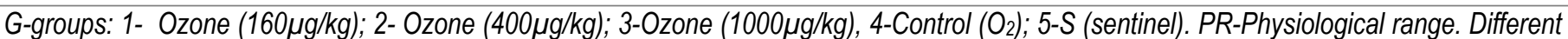
letters indicate significant differences $p<0.05$.

Table 7. Behavior of some biomarkers in rats submitted to 28 days of ozone by rectal insufflation.

\begin{tabular}{ccccccccc}
\hline & \multicolumn{2}{c}{ Alkaline phosphatase (U/L) } & Alanine aminotransferase (U/L) & \multicolumn{2}{c}{ Aspartate aminotransferase (U/L) } & \multicolumn{2}{c}{ Total proteins (g/L) } \\
G & Day 7 & Day 28 & Day 7 & Day 28 & Day 7 & Day 28 & Day 28 \\
\hline 1 & $129 \pm 48$ & $84 \pm 49$ & $20 \pm 11^{\mathrm{a}}$ & $19 \pm 9$ & $28 \pm 8^{\mathrm{a}}$ & $34 \pm 14^{\mathrm{a}}$ & $70 \pm 16^{\mathrm{a}}$ & $47 \pm 5$ \\
2 & $163 \pm 47$ & $99 \pm 52$ & $26 \pm 13^{\mathrm{a}}$ & $24 \pm 13$ & $49 \pm 14^{\mathrm{b}}$ & $55 \pm 27^{\mathrm{b}}$ & $44 \pm 6^{\mathrm{b}}$ & $45 \pm 7$ \\
3 & $119 \pm 84$ & $118 \pm 57$ & $38 \pm 12^{\mathrm{b}}$ & $17 \pm 9$ & $56 \pm 20^{\mathrm{b}}$ & $39 \pm 11^{\mathrm{b}}$ & $45 \pm 7^{\mathrm{b}}$ & $47 \pm 8$ \\
4 & $126 \pm 52$ & $106 \pm 59$ & $17 \pm 4^{\mathrm{a}}$ & $18 \pm 8$ & $26 \pm 16^{\mathrm{a}}$ & $50 \pm 18^{\mathrm{b}}$ & $45 \pm 10^{\mathrm{b}}$ & $45 \pm 6$ \\
$\mathrm{~S}$ & - & $66 \pm 25$ & - & $39 \pm 8$ & - & $39 \pm 8$ & & $43 \pm 5$ \\
\hline
\end{tabular}

$\begin{array}{llll}\text { PR } & 39-216 & 17-50 & 39-92\end{array}$

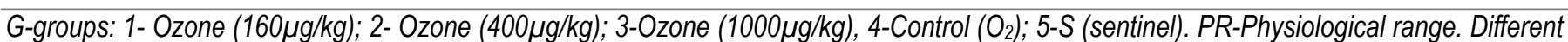
letters indicate significant differences $p<0.05$. 
physiological range, indicating that this effect can not be associated to ozone treatment (Table 7). A decrease in the level of serum total proteins is reported in cases of exposition to benzene, carbon tetrachloride, phosgene and estrogens, as well as in poor nutrition or malabsorption. Also, it can be seen in the reduction of protein diets, hepatic diseases and in the chronic use of laxatives.

Glucose levels are associated with the hepatic and renal functioning. The increase of their values (hyperglycemia) has been reported in cases of pancreatitis, diabetes mellitus, infections, renal and hepatic chronic failures, etc $[37,38]$. At day 7 th, an increase of the glucose levels, with respect to physiological range, were seen in all the groups, with the highest value achieved in the control group $(p<0.05)$. However, at day 28th, only the low ozone dose and the control remained with the highest values. In the sentinel group, its mean value was within the physiological range, indicating a reversibility of the effect (Table 8 ).

Cholesterol is the unsaturated steroid alcohol most abundant in tissues and biological fluids [38]. In this study this parameter remained within the physiological range for all the experimental groups. However, a significant decrease was obtained at day 7 in the low ozone dose with respect to the rest of the groups and at day 28 in the low ozone dose and the control with respect to the medium and high ozone doses (Table 8). This can be considered as a mathematical difference but with no biological effect, due that all these values were within the physiological range.

As a measure of renal damage, plasma urea levels were determined. Urea is generally increased in cases of renal toxicity, in severe hepatic damage or in diseases that involve an increase of protein metabolism [37]. In our study occurred as in the case of total proteins, all the values were below the physiological range, indicating that this effect can not be associated to ozone treatment (Table 8). The significant differences observed among the groups can be considered as a mathematical difference, but with no biological significance.

Taking into account the variations occurred in the biochemical parameters analyzed, it can be concluded that they can not be related to the ozone treatment.

The histological study of lung, heart, liver, kidneys, stomach, spleen, intestines, brain and rectum demonstrated the presence of no damages in

Table 8. Behavior of some biomarkers in rats submitted to 28 days of ozone by rectal insufflation.

\begin{tabular}{|c|c|c|c|c|c|c|}
\hline \multirow[t]{2}{*}{ G } & \multicolumn{2}{|c|}{ Glucose (mmol/L) } & \multicolumn{2}{|c|}{ Cholesterol (mmol/L) } & \multicolumn{2}{|c|}{ Urea (mmol/L) } \\
\hline & Day 7 & Day 28 & Day 7 & Day 28 & Day 7 & Day 28 \\
\hline 1 & $8.09 \pm 1.44 a$ & $8.09 \pm 1.44 a$ & $1.40 \pm 0.25^{a}$ & $1.54 \pm 0.45^{a}$ & $5.51 \pm 0.55^{a}$ & $5.17 \pm 2.62^{a}$ \\
\hline 2 & $7.79 \pm 1.15^{a}$ & $6.41 \pm 1.57 b$ & $1.74 \pm 0.31 \mathrm{~b}$ & $2.29 \pm 0.37 \mathrm{~b}$ & $6.95 \pm 1.67 b$ & $10.0 \pm 2.78^{b}$ \\
\hline 3 & $8.06 \pm 1.09 a$ & $6.28 \pm 0.97 \mathrm{~b}$ & $1.75 \pm 0.35^{b}$ & $2.06 \pm 0.48 \mathrm{~b}$ & $6.66 \pm 1.14^{b}$ & $7.75 \pm 3.35^{a}$ \\
\hline 4 & $110.16 \pm 2.21 b$ & $10.15 \pm 2.20^{a}$ & $1.64 \pm 0.31 \mathrm{~b}$ & $1.69 \pm 0.22^{\mathrm{a}}$ & $5.51 \pm 0.95^{a}$ & $7.26 \pm 3.08^{a}$ \\
\hline$S$ & - & $7.14 \pm 1.35$ & - & $1.80 \pm 0.57$ & - & $9.09 \pm 1.84$ \\
\hline
\end{tabular}


the organs studied. With the analysis of all these studies, it can be concluded that the application of ozone by $\mathrm{RI}$ during 28 days did not produce any toxicity in rats.

B.- Results of the sub-chronic toxicity of ozone by RI, performed in New Zeland rabbit during 90 days:

The study finished with $98 \%$ of survival. One animal died (with the high ozone dose) at the day 52nd of the study and the other, treated with the low ozone dose, showed a deterioration of the general state at the day 53rd and considering that the animal was in a critical state, it was decided to sacrifice it. The histological study confirmed the presence of gram negative pyogenic microorganisms provoking septicemia and bacterial pneumonia. No relation to the ozone treatment was confirmed.

As in the acute toxicity study, daily cage-side observations did not reveal, in the rest of the animals, any physical changes or toxic symptoms in clinical observations, with a normal behaviour as reported for this specie $[39,40]$.

Both sexes increased gradually their weight, since the first day of the study up to the 90th day (end of the study), with a slight increase in females. No significant differences $(p>0.05)$ were observed between the groups, considering only the highest ozone dose, as a better proof of the presence of any side effect (Table 9). Also, when it is compared the mean weight, gained at the end of the treatment, no significant differences were observed between the groups (the same for the low and medium ozone doses). This is an evidence of the absence of toxic effects associated to the ozone treatment.

The behaviour of the 6 animals ( 3 per sex) treated with the high ozone dose that remained alive during 3 weeks post treatment is seen in Figure 3 . It is

Table 9. Behavior of the body weight $(\mathrm{g})$ in the control and high ozone dose groups, in respect to each sex and the weeks which it was measured.

\begin{tabular}{ccccc}
\hline Weeks & \multicolumn{2}{c}{ Control $\left(\mathrm{O}_{2}\right)$} & \multicolumn{2}{c}{ Ozone $(1209 \mu \mathrm{gg} / \mathrm{kg})$} \\
& Female & Male & Female & Male \\
\hline 0 & $1997 \pm 128$ & $2046 \pm 104$ & $2170 \pm 39$ & $2139 \pm 289$ \\
1 & $2072 \pm 178$ & $2077 \pm 41$ & $2043 \pm 200$ & $2228 \pm 277$ \\
2 & $2151 \pm 185$ & $2204 \pm 91$ & $2360 \pm 134$ & $2323 \pm 265$ \\
3 & $2183 \pm 261$ & $2239 \pm 131$ & $2467 \pm 112$ & $2349 \pm 256$ \\
4 & $2243 \pm 209$ & $2313 \pm 102$ & $2486 \pm 172$ & $2463 \pm 258$ \\
5 & $2274 \pm 195$ & $2344 \pm 103$ & $2555 \pm 86$ & $2471 \pm 269$ \\
6 & $2366 \pm 196$ & $2384 \pm 112$ & $2599 \pm 156$ & $2525 \pm 296$ \\
7 & $2401 \pm 182$ & $2434 \pm 119$ & $2663 \pm 150$ & $2584 \pm 286$ \\
8 & $2399 \pm 163$ & $2426 \pm 107$ & $2672 \pm 123$ & $2583 \pm 288$ \\
9 & $2460 \pm 153$ & $2451 \pm 98$ & $2685 \pm 158$ & $2631 \pm 298$ \\
10 & $2471 \pm 160$ & $2431 \pm 125$ & $2611 \pm 203$ & $2600 \pm 299$ \\
11 & $2498 \pm 174$ & $2469 \pm 126$ & $2712 \pm 198$ & $2638 \pm 288$ \\
12 & $2581 \pm 134$ & $2481 \pm 124$ & $2742 \pm 153$ & $2564 \pm 270$ \\
13 & $2574 \pm 161$ & $2471 \pm 133$ & $2729 \pm 176$ & $2539 \pm 363$ \\
\hline
\end{tabular}


observed a slight decrease in females ( 2 of them) between the weeks 13 and 14. This behaviour can be associated with the stress caused in the animals during the blood extraction and not because of any particular clinical sign. Afterwards, the weight gained became normal.

The hematological responses of rabbits submitted to 90 days of ozone by RI demonstrated no significant effects ( $p>0.05$ ) among the groups, all the values were within the physiological range in the evaluations performed before and at the end of the treatment (week 13). It was measured: hemoblobin, erythrocyte, hematocrit, medium corpuscular volume (MCV), medium corpuscular haemoglobin $(\mathrm{MCH})$ and medium corpuscular haemoglobin concentration (MCHC), total and differential count of leukocytes (this last one included neutrophils, lymphocytes, monocytes and eosinophils) and platelets. The comparison of the mean values of some hematological parameters (at week 13), corresponding to the different groups and sex, is observed in Table 10.

The 6 animals that remained alive, during 3 weeks more, after the ozone treatment, had a similar behaviour as the rest of the groups, maintaining their hematological values within the physiological range.

The calculated blood indices - MCV, $\mathrm{MCH}$ and $\mathrm{MCHC}$ have a particular importance in anaemia diagnosis in most animals [41]. The non-significant effect on these indices relating to RBC suggests that there was no effect on the average size of RBC and also on the haemoglobin weight per RBC.

Administration of a chemical compound may bring about significant changes in the structure, function, metabolic transformation and concentration of biomolecules, enzymes and even metabolic pathways. These alterations, which may be rapid or slow may lead to different biochemical mechanisms producing similar pathological, clinical and laboratory findings [42]. Assessment of hematological parameters can be used to determine the extent of deleterious effect of foreign compound on the blood. Such laboratory investigations have been reported to be highly sensitive, accurate, and reliable and it remains the basis of ethical and rational research, disease diagnosis, prevention and treatment [43].

The results of the biochemical parameters demonstrated no significant differences ( $p>0.05)$ among the groups, all the values were within the physiological range in the evaluations performed before and at the end of the treatment (week 13). The behaviour of some of these biochemical parameters, at the end of the treatment and for both sexes, is shown in Table 11. The values of bilirubin and triglycerides did not appear in the table, but neither non significant effects were observed in both parameters.

Table 10. Hematological responses of rabbits submitted to 90 days (week 13) of ozone by rectal insufflation.

\begin{tabular}{|c|c|c|c|c|c|c|c|c|}
\hline \multirow[b]{2}{*}{ G } & \multicolumn{2}{|c|}{ Hemoglobin (g/dL) } & \multicolumn{2}{|c|}{ Hematocrit (\%) } & \multicolumn{2}{|c|}{ 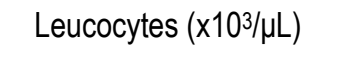 } & \multicolumn{2}{|c|}{ 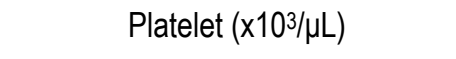 } \\
\hline & Female & Male & Female & Male & Female & Male & Female & Male \\
\hline 1 & $11.2 \pm 0.2$ & $12.2 \pm 0.9$ & $39.7 \pm 0.9$ & $42.7 \pm 2.9$ & $6.6 \pm 2.0$ & $7.6 \pm 2.5$ & $235.2 \pm 69.6$ & $252.0 \pm 56.9$ \\
\hline 2 & $11.6 \pm 0.6$ & $11.6 \pm 0.9$ & $41.2 \pm 2.2$ & $41.6 \pm 3.4$ & $6.3 \pm 0.9$ & $6.4 \pm 0.9$ & $261.6 \pm 69.6$ & $248.0 \pm 25.7$ \\
\hline 3 & $11.8 \pm 1.3$ & $12.1 \pm 1.2$ & $41.2 \pm 5.0$ & $43.3 \pm 4.2$ & $6.5 \pm 2.4$ & $6.8 \pm 0.7$ & $304.4 \pm 41.7$ & $228.8 \pm 54.3$ \\
\hline 4 & $11.9 \pm 1.2$ & $11.6 \pm 1.2$ & $44.4 \pm 7.3$ & $40.7 \pm 4.3$ & $6.7 \pm 1.4$ & $7.3 \pm 1.4$ & $437.3 \pm 278.9$ & $249.7 \pm 35.6$ \\
\hline PR & $10.0-13.4$ & $10.2-13.6$ & $34.1-50.5$ & $36.4-49.2$ & $3.1-10.1$ & $4.0-10.1$ & $139.1-639.3$ & $155.3-656.4$ \\
\hline
\end{tabular}


Table 11. Behavior of some biomarkers in rabbits submitted to 90 days (week 13) of ozone by rectal insufflation.

\begin{tabular}{ccccccccc}
\hline & \multicolumn{2}{c}{ Aspartate aminotransferase $(\mathrm{U} / \mathrm{L})$} & \multicolumn{2}{c}{ Alanine aminotransferase(U/L) } & \multicolumn{2}{c}{ Total proteins $(\mathrm{g} / \mathrm{L})$} & \multicolumn{2}{c}{ Albumin $(\mathrm{g} / \mathrm{L})$} \\
$\mathrm{G}$ & Female & Male & Female & Male & Female & Male & Female & Male \\
\hline 2 & $36.8 \pm 9.2$ & $49.0 \pm 15.4$ & $55.2 \pm 8.0$ & $75.1 \pm 13.4$ & $67.0 \pm 7.4$ & $63.4 \pm 4.7$ & $34.5 \pm 1.9$ & $33.8 \pm 1.3$ \\
3 & $40.5 \pm 11.2$ & $40.4 \pm 10.2$ & $68.5 \pm 24.8$ & $66.0 \pm 18.3$ & $66.2 \pm 8.3$ & $55.2 \pm 3.8$ & $32.2 \pm 2.8$ & $32.9 \pm 2.4$ \\
4 & $39.4 \pm 9.6$ & $48.7 \pm 12.2$ & $63.4 \pm 19.0$ & $73.3 \pm 21.1$ & $65.5 \pm 9.3$ & $58.3 \pm 6.7$ & $32.8 \pm 3.7$ & $32.3 \pm 2.8$ \\
\hline PR & $0-105.7$ & $17.5-53.7$ & $0.6-92.6$ & $11.3-75.8$ & $44.7-73.0$ & $47.6-64.7$ & $31.3-39.8$ & $31.2-38.1$ \\
\hline & Glucose $(\mathrm{mmol} / \mathrm{L})$ & Cholesterol $(\mathrm{mmol} / \mathrm{L})$ & Urea $(\mathrm{mmol} / \mathrm{L})$ & Creatinine $(\mu \mathrm{mol} / \mathrm{L})$ \\
$\mathrm{G}$ & Female & Male & Female & Male & Female & Male & Female & Male \\
\hline 1 & $3.99 \pm 0.73$ & $4.55 \pm 0.36$ & $2.40 \pm 0.45$ & $1.50 \pm 0.49$ & $9.24 \pm 0.98$ & $7.76 \pm 1.80$ & $132.0 \pm 15.8$ & $129.3 \pm 14.0$ \\
2 & $4.91 \pm 0.80$ & $6.87 \pm 2.09$ & $2.42 \pm 0.60$ & $1.06 \pm 0.24$ & $9.64 \pm 0.83$ & $7.90 \pm 0.57$ & $139.4 \pm 8.8$ & $139.0 \pm 18.4$ \\
3 & $4.61 \pm 0.73$ & $4.72 \pm 0.75$ & $2.62 \pm 1.13$ & $1.47 \pm 0.36$ & $9.02 \pm 1.02$ & $7.21 \pm 0.92$ & $146.3 \pm 9.9$ & $131.2 \pm 8.7$ \\
4 & $4.57 \pm 0.76$ & $5.75 \pm 0.94$ & $1.92 \pm 0.49$ & $1.46 \pm 0.88$ & $8.32 \pm 0.91$ & $7.10 \pm 1.42$ & $132.0 \pm 5.9$ & $130.1 \pm 7.5$ \\
\hline PR & $2.92-6.65$ & $4.24-6.65$ & $0.68-3.85$ & $0.25-3.27$ & $5.74-10.8$ & $4.99-9.33$ & $104.9-164.4$ & $94.4-143.2$ \\
\hline
\end{tabular}

The 6 animals that remained alive, during 3 weeks more, after the ozone treatment, had a similar behaviour as the rest of the groups, maintaining their biochemical parameters values within the physiological range.

The liver is one of the most important organs in the body and is responsible for breaking down all 'poisons' that enter the body and liver diseases could be mild or severe. Liver function tests conducted through blood assays give information about the state of the liver, describing its functionality, e.g. albumin, cellular integrity, transaminases and its link with the biliary tract. ALT is the enzyme produced within the cells of the liver, recording increases in conditions where liver cells have been inflamed or undergone cell death. As the cells are damaged, the ALT leaks into the bloodstream leading to a rise in the serum levels. It is the most sensitive marker for liver cell damage.

Histopathological effect of repeated rectal ozone applications on selected vital organs (spleen, kidney, liver, ovary, testis, thymus, heart, lung, encephalon) of rabbits did not reveal any morphological changes on gross and histological examinations in the different experimental groups studied. The effect of ozone on weights of some vital body organs, in female and male rats, showed no significant difference in the organ weight in treated (with the highest ozone dose and after $21 \mathrm{~d}$ ) and control groups (Table 12).

In the histological study, using the highest ozone dose, no anatomopathological changes of circulatory, degenerative or inflammatory character, in the site of application, were observed. The circulatory epithelium was intact. It is worth noting to observe the increase in the number of lymphocytes and the development of lymphoid follicles with germinal centers. On the other hand, such an increase was not enough to obtain significant differences in the spleen weight of the different groups with respect to control. These changes can be considered as an immunomodulatory action of ozone. Ozone treatment stimulates several cytokines, among them is interleukin 2 (IL-2), one of the main cytokines in the immune system. It is segregated by T-helper cells and by a process of 
Table 12. Comparison of the weight of different organs among the ozone group, with the highest dose and after 21 days and the control treated with oxygen, for both sexes.

\begin{tabular}{lcccccc}
\hline Organs & \multicolumn{3}{c}{ Female weight $(\mathrm{g})$} & \multicolumn{3}{c}{ Male weight $(\mathrm{g})$} \\
& Control & $\mathrm{O}_{3}$ & $\mathrm{O}_{3}(21 \mathrm{~d}$ later $)$ & Control & $\mathrm{O}_{3}$ & $\mathrm{O}_{3}(21 \mathrm{~d}$ later $)$ \\
\hline Thymus & $2.05 \pm 0.86$ & $1.88 \pm 0.51$ & $2.42 \pm 0.71$ & $2.06 \pm 0.40$ & $1.94 \pm 0.71$ & $2.14 \pm 0.41$ \\
Spleen & $0.84 \pm 0.26$ & $1.01 \pm 0.26$ & $0.97 \pm 0.24$ & $0.83 \pm 0.17$ & $0.71 \pm 0.18$ & $0.78 \pm 0.11$ \\
Heart & $5.32 \pm 0.66$ & $6.11 \pm 0.60$ & $5.80 \pm 0.19$ & $5.59 \pm 0.49$ & $5.64 \pm 0.47$ & $5.09 \pm 0.20$ \\
Encephalon & $8.82 \pm 0.58$ & $8.10 \pm 0.52$ & $8.44 \pm 0.46$ & $8.76 \pm 0.30$ & $8.06 \pm 1.36$ & $8.44 \pm 0.38$ \\
Liver & $52.64 \pm 7.08$ & $53.17 \pm 7.27$ & $55.44 \pm 11.90$ & $51.22 \pm 4.77$ & $49.59 \pm 6.45$ & $54.45 \pm 13.08$ \\
Kidney & $12.06 \pm 1.71$ & $12.08 \pm 0.93$ & $12.33 \pm 2.28$ & $11.72 \pm 0.63$ & $12.30 \pm 0.82$ & $11.83 \pm 1.41$ \\
Lung & $8.29 \pm 0.66$ & $8.56 \pm 1.13$ & $9.06 \pm 1.44$ & $8.59 \pm 0.49$ & $9.36 \pm 1.15$ & $9.55 \pm 0.82$ \\
\hline
\end{tabular}

Note: The ozone dose applied was the highest, equivalent to $1209 \mu \mathrm{g} / \mathrm{kg}$. In the other group, 6 animals (3 per sex) treated with the highest ozone dose remained alive for 21 days after the last ozone treatment.

auto stimulation, the IL-2 stimulates T-helper cells to produce more IL-2, which in turn increase the production of $T$ lymphocytes $[7,13,44]$. These interactions permit the increase and proliferation of lymphocytes in the lymphoid tissue, as it was seen in this study, even when the ozone treatment was finished. It has been reported that granulocyte-macrophage colony stimulating factor, macrophage colony stimulating factor, interleukins IL-2, IL-4 and IL-5 regulate the proliferation, differentiation and maturation of committed stem cells responsible for the production of white blood cells $[45,46]$.

It can be concluded that the ozone applied by $\mathrm{RI}$ during 90 days to rabbits did not produce any clinical sign of toxicity, neither any alteration of the body weight, of the hematological and biochemical parameters and of the microscopic exam. The occurred deaths can not be related to the ozone treatment, as they were demonstrated. Another study performed in rabbits

\subsection{2.- Ozone by IP:}

Results of the sub-chronic toxicity of ozone by IP application, performed in mice during 15 days demonstrated no toxic signs or symptoms related to the ozone application. All animals were normal. The daily cage-side observations did not reveal any physical changes or toxic symptoms in clinical observations.

With respect to the body weight, male mice increased gradually their weight, since the first day of the study up to the 15th day (end of the study). No significant differences ( $p>0.05)$ were observed among the different groups (Table 13). Also, when it is compared the mean weight gained at the end of the treatment, no significant differences were observed among the different groups. This is an evidence of the absence of toxic effects associated to the ozone treatment. 
Table 13. Behavior of the body weight $(\mathrm{g})$ of the mice, during the 15 days of ozone treatment by IP application, in the different groups.

\begin{tabular}{lrrrrrrr}
\hline \multirow{2}{*}{ Groups } & \multicolumn{9}{c}{ Time of Treatment (days) } & $\begin{array}{c}\text { Weight gained } \\
\text { (g/day) }\end{array}$ \\
\cline { 2 - 6 } & 0 & 2 & 7 & 11 & 13 & 15 & \\
\hline Control $\left(\mathrm{O}_{2}\right)$ & $21.5 \pm 0.1$ & $20.3 \pm 0.2$ & $21.4 \pm 0.1$ & $21.6 \pm 0.1$ & $21.9 \pm 0.2$ & $22.4 \pm 0.5$ & 0.06 \\
$\mathrm{O}_{3}(4 \mathrm{mg} / \mathrm{L})$ & $19.8 \pm 0.1$ & $19.7 \pm 0.3$ & $20.4 \pm 0.3$ & $20.6 \pm 0.3$ & $20.7 \pm 0.3$ & $20.9 \pm 0.3$ & 0.07 \\
$\mathrm{O}_{3}(11 \mathrm{mg} / \mathrm{L})$ & $21.0 \pm 0.3$ & $20.7 \pm 0.4$ & $20.9 \pm 0.2$ & $21.6 \pm 0.2$ & $21.7 \pm 0.4$ & $22.7 \pm 0.2$ & 0.09 \\
$\mathrm{O}_{3}(20 \mathrm{mg} / \mathrm{L})$ & $20.3 \pm 0.2$ & $20.0 \pm 0.3$ & $20.1 \pm 0.4$ & $20.8 \pm 0.4$ & $21.2 \pm 0.3$ & $21.4 \pm 0.3$ & 0.07 \\
$\mathrm{O}_{3}(35 \mathrm{mg} / \mathrm{L})$ & $20.7 \pm 0.1$ & $20.8 \pm 0.2$ & $21.0 \pm 0.1$ & $21.2 \pm 0.1$ & $21.7 \pm 0.2$ & $22.0 \pm 0.4$ & 0.09 \\
\hline
\end{tabular}

Note: It was used in all animals a volume of $80 \mathrm{~mL} / \mathrm{kg}$. The weight gained was measured at the end of the 15 days of treatment.

\section{2.- Rectal irritation in New Zeland rabbits}

The daily cage-side observations did not reveal any physical changes or toxic symptoms in clinical observations. All animals were normal.

With respect to the body weight, male rabbits increased gradually their weight, since the first day of the study up to the 15h day (end of the study). No significant differences ( $p>0.05)$ were observed among the different groups (Table 14). Also, when it is compared the mean weight gained at the end of the treatment, no significant differences were observed among the different groups.

The daily local observation of the perineum appearance demonstrated the absence of any toxic sign. The results showed that the daily scores for secretion, erythema and oedema were 0 , which was the same to controls. The rectum macroscopic evaluation did not present any signs of toxic effect. No obvious pathological changes were found in all organs by gross appearance.

In the microscopic observations, it was reported: normal epithelium and lack of oedema, leukocyte infiltration and vascular congestion for all the samples analyzed, assigning a value of 0 .

According to the irritation scoring (equal to 0), all the rabbits did not show any toxic symptom, therefore, it can be concluded that ozone is not a rectal irritant after its application by this route at repeated doses.

Table 14. Behavior of the body weight $(\mathrm{g})$ of the rabbits, during the 15 days of ozone treatment by $\mathrm{Rl}$, in the different groups.

\begin{tabular}{lcccc}
\hline Group & \multicolumn{3}{c}{ Weight $(\mathrm{kg})$} & Weight gained $(\mathrm{kg})$ \\
& Day 0 & Day 7 & Day 15 & \\
\hline Control $\left(\mathrm{O}_{2}\right)$ & $2.217 \pm 0.142$ & $2.220 \pm 0.110$ & $2.316 \pm 0.009$ & 0.099 \\
$\mathrm{O}_{3}(184 \mu \mathrm{g} / \mathrm{kg})$ & $2.178 \pm 0.109$ & $2.188 \pm 0.008$ & $2.278 \pm 0.021$ & 0.100 \\
Placebo $(\mathrm{NaCl} 0.9 \%)$ & $2.112 \pm 0.007$ & $2.171 \pm 0.009$ & $2.251 \pm 0.007$ & 0.139 \\
\hline
\end{tabular}




\section{3.- Mutagenesis assay}

\section{1.- On bone marrow by RI}

The results of the study of the ozone mutagenic effect by RI, evaluated by its ability to induce micronuclei in the bone marrow of Sprague-Dawley rats, is shown in Table 15. No statistical differences were seen in the number of chromosomic aberrations among the ozone (using an ozone concentration of 50 and $75 \mathrm{mg} / \mathrm{L}$ ) and the negative control groups. However, positive control group increased its number with significant differences in respect to the other groups.

This result indicated that any cytotoxic effect in the bone marrow of the rats treated with ozone were present. Similarly, no significant increase was found in the number of aberrations/cells for the two ozone doses, for both sexes.

The ozone mutagenic effect by RI, evaluated by its ability to induce micronuclei in the bone marrow, was also studied in mice of both sexes. The numbers of micronucleated polychromatic erythrocytes-PCE (genotoxicity index) and the percentage of PCE and normochromatic erythrocytes (NCE) in all the groups were shown in Table 16. There was a significant difference in the numbers of micronucleated PCE between the positive control group and all the other groups $(p<0.05)$. However, there was no significant difference between the two ozone doses and the negative control group $(p>0.05)$. In all the test groups, the PCE numbers were almost the same between the males and females.

It can be concluded that one administration of ozone by $\mathrm{Rl}$, at the concentrations studied, do not produce any clastogenic or cytotoxic effects in the bone marrow of rats and mice.

Table 15. Number of chromosomic aberrations in the different groups, considering male and female together.

\begin{tabular}{lcccc}
\hline Groups $(\mathrm{n}=10)$ & Cells & $\begin{array}{c}\text { Total number of } \\
\text { aberrations }\end{array}$ & $\begin{array}{c}\text { Aberrations/cells } \\
\text { Mean of the total number of } \\
\text { aberrations }\end{array}$ \\
\hline Negative control $\left(\mathrm{O}_{2}\right)$ & 500 & 6 & 0.012 & $0.60 \pm 0.70$ \\
$\mathrm{O}_{3}(1250 \mu \mathrm{g} / \mathrm{kg})$ & 500 & 6 & 0.012 & $0.60 \pm 0.70$ \\
$\mathrm{O}_{3}(1875 \mu \mathrm{g} / \mathrm{kg})$ & 500 & 8 & 0.016 & $0.80 \pm 0.79$ \\
Positive controla & 500 & $158^{*}$ & $0.316^{*}$ & $15.80 \pm 3.77^{*}$
\end{tabular}

${ }^{*} p<0.05$ (in respect to the other groups). aUsing cyclophosphamide $(40 \mathrm{mg} / \mathrm{kg}$ ) as positive control.

Table 16. Percentage of micronuclei and genotoxicity index in the different groups, for both sexes.

\begin{tabular}{llllll}
\hline Groups $(\mathrm{n}=5)$ & Total number of PCE & MN-PCE & \multicolumn{3}{l}{ PCE/NCE } \\
& & Female & Male & Female & Male \\
\hline Negative control $\left(\mathrm{O}_{2}\right)$ & 5000 & $0.40 \pm 0.89$ & $0.40 \pm 0.55$ & $1.63 \pm 0.21$ & $1.48 \pm 0.21$ \\
$\mathrm{O}_{3}(3333 \mu \mathrm{g} / \mathrm{kg})$ & 5000 & $0.40 \pm 0.55$ & $0.40 \pm 0.55$ & $1.54 \pm 0.13$ & $1.33 \pm 0.10$ \\
$\mathrm{O}_{3}(5000 \mu \mathrm{g} / \mathrm{kg})$ & 5000 & $0.60 \pm 0.89$ & $0.80 \pm 0.84$ & $1.41 \pm 0.08$ & $1.39 \pm 0.11$ \\
Positive controla & 5000 & $7.00 \pm 1.58^{*}$ & $6.60 \pm 3.78^{*}$ & $1.17 \pm 0.09^{*}$ & $1.19 \pm 0.26^{*}$ \\
\hline
\end{tabular}

${ }^{*} p<0.05$ (in respect to the other groups). aUsing cyclophosphamide $(40 \mathrm{mg} / \mathrm{kg}$ ) as positive control. 


\section{2.- On leukocytes in vitro}

The results of the study of the genotoxic effect of ozone in human leukocytes in vitro [47], using the single cell gel electrophoresis (SCGE) assay is shown in Table 17. It is observed the DNA migration measurements (image length in $\mu \mathrm{m}$ ) after treatments of blood leukocytes from 6 healthy with $\mathrm{O}_{3}$ in vitro. In spite of some individual variation with regard to the distribution of comet lengths, there was a clear effect of $\mathrm{O}_{3}$ with respect to the fraction of damaged cells (data not shown), as well as the comet length. The compiled data from the 6 donors showed an ozone dose dependent effect. Preincubation of cells from 2 donors with catalase for 15 min significantly decreased the percentages of damaged cells (data not shown) and comet length, even in the control, compared with the corresponding treatments without catalase $(p<0.01)$, suggesting that hydrogen peroxide $\left(\mathrm{H}_{2} \mathrm{O}_{2}\right)$ is the main mediator of these effects. However, the damage levels in the catalasepre-treated cells exposed to $\mathrm{O}_{3}$ were still significantly higher $(p<0.05)$ than in the untreated catalase control, suggesting that other intermediaries in addition to $\mathrm{H}_{2} \mathrm{O}_{2}$ were causing DNA damage as well. The use of catalase to protect against the genotoxic effects of $\mathrm{H}_{2} \mathrm{O}_{2}$ has also been applied in other in vitro systems with similar results [48,49].

Cells from 4 donors treated with the highest dose of $\mathrm{O}_{3}(50 \mu \mathrm{g})$ were allowed to recover in the incubator for 45 or $90 \mathrm{~min}$. In all cases, this post-treatment incubation reduced the percentages of damaged cells (data not shown) and the image length to control levels, indicating that the cells recover rapidly

Table 17. Tail image length $(\mu \mathrm{m})$ in human leukocytes after ozone treatment.

\begin{tabular}{|c|c|c|c|c|c|c|}
\hline Dose $(\mu \mathrm{g})$ & Donor 1 & Donor 2 & Donor 3 & Donor 4 & Donor 5 & Donor 6 \\
\hline \multicolumn{7}{|c|}{ Without catalase pre-treatment } \\
\hline Control & $19.95 \pm 6.75$ & $19.71 \pm 5.47$ & $20.83 \pm 6.25$ & $19.69 \pm 4.86$ & $22.13 \pm 10.63$ & $16.63 \pm 7.25$ \\
\hline $\mathrm{O}_{3}(20)$ & $33.51 \pm 17.95^{\star}$ & $38.30 \pm 14.48^{*}$ & $39.55 \pm 13.84^{*}$ & $40.25 \pm 14.39^{*}$ & $39.56 \pm 16.81^{*}$ & $34.61 \pm 14.40^{*}$ \\
\hline $\mathrm{O}_{3}(30)$ & $46.37 \pm 29.13^{*}$ & $50.29 \pm 16.70^{*}$ & $39.86 \pm 13.02^{*}$ & $46.17 \pm 15.21^{*}$ & $60.20 \pm 19.13^{*}$ & $57.54 \pm 9.75^{*}$ \\
\hline $\mathrm{O}_{3}(40)$ & $39.47 \pm 22.43^{*}$ & $55.42 \pm 18.38^{*}$ & $45.04 \pm 12.49^{*}$ & $49.43 \pm 17.42^{*}$ & $62.88 \pm 23.39^{*}$ & $71.16 \pm 13.65^{*}$ \\
\hline $\mathrm{O}_{3}(50)$ & $55.82 \pm 25.48^{*}$ & $71.73 \pm 19.67^{*}$ & $43.78 \pm 14.60^{*}$ & $55.78 \pm 16.42^{*}$ & $83.00 \pm 26.90^{*}$ & $70.49 \pm 22.12^{*}$ \\
\hline \multicolumn{7}{|c|}{$\mathrm{O}_{3}(50 \mu \mathrm{g})$ post-treatment incubation } \\
\hline $45 \mathrm{~min}$ & $23.28 \pm 14.02$ & $23.40 \pm 9.04$ & $19.87 \pm 6.21$ & $19.56 \pm 5.07$ & ND & ND \\
\hline $90 \mathrm{~min}$ & $21.01 \pm 9.0$ & $19.75 \pm 5.84$ & $19.83 \pm 6.44$ & $20.10 \pm 5.58$ & ND & ND \\
\hline
\end{tabular}

With catalase pre-treatment

Control

$\mathrm{O}_{3}(20)$

$\mathrm{O}_{3}(30)$

$\mathrm{O}_{3}(40)$

$\mathrm{O}_{3}(50)$

$\begin{array}{ll}16.98 \pm 8.71 & 16.43 \pm 6.85 \\ 20.39 \pm 8.53^{*} & 19.88 \pm 9.41^{*} \\ 21.10 \pm 7.12^{*} & 20.34 \pm 9.95^{*} \\ 21.82 \pm 10.42^{*} & 22.18 \pm 9.57^{*} \\ 22.77 \pm 12.68^{*} & 24.51 \pm 18.48^{*}\end{array}$

DNA migration mean of 50 cells \pm SE per data treatment point. ND-Not done. ${ }^{*} p<0.05$ (significant differences in respect to non-treated control). 
from the genotoxic effect of $\mathrm{O}_{3}$ treatment (Table 17).

These results show that exposure of blood leukocytes to $\mathrm{O}_{3}$ gives rise to an immediate and dose-dependent increase of DNA damage that is rapidly reversed during prolonged incubation, and it is likely to be mediated mainly by $\mathrm{H}_{2} \mathrm{O}_{2}$, because most of the effect is prevented by pre-incubation with catalase.

\section{3.- On leukocytes in vivo by M-AHT}

The results of the genotoxic effect of ozone in patients treated with ozone by $\mathrm{M}-\mathrm{AHT}$, by means of chromosomal aberrations, frequency of sister chromatid exchange and mycronucleus test, are shown in Table 18.

Table 18. Results of the frequencies of Chromosomal Aberration and Micronuclei, as well as the Sister Chromatid Exchange (SCE) mean, in peripheral blood lymphocytes of patients treated with ozone by M-AHT, before and after the 15 sessions of ozone therapy treatment.

\begin{tabular}{|c|c|c|c|c|c|}
\hline \multicolumn{6}{|c|}{ Chromosomal Aberration $(n=14)$} \\
\hline \multicolumn{2}{|c|}{ Chromosomal break $(\mu \pm S D)$} & \multicolumn{2}{|c|}{ Chromatidic break $(\mu \pm S D)$} & \multicolumn{2}{|c|}{ Gaps } \\
\hline Initial & Final & Initial & Final & Initial & Final \\
\hline $0.0010 \pm 0.0006$ & $0.0070 \pm 0.0009$ & $0.0107 \pm 0.0010$ & $0.0071 \pm 0.0008$ & $0.0107 \pm 0.0011$ & $0.0093 \pm 0.0009$ \\
\hline
\end{tabular}

Sister Chromatid Exchange $(n=18)$

SCE/cells (total number of exchanged by the total number of cells scored in a patient) Initial

Final

$6.91 \pm 1.43$

$6.62 \pm 1.54$

\section{Micronucleus test $(n=10)$}

\begin{tabular}{cccc}
\hline $\begin{array}{c}\text { Initial } \\
\text { Binucleated cells (total) }\end{array}$ & MN/cells $(\mu \pm S D)$ & Binucleated cells (total) & Final \\
\hline 4641 & $0.0085 \pm 0.0059$ & 4309 & $0.0103 \pm 0.0065$ \\
\hline$\mu$ - frequencies (are the result of the division of number of aberrations per 100 cells); SD-standard deviation; $n$-number of patients; $(p>0.05)$.
\end{tabular}

Micronuclei (MN) results reinforce that of chromosomal aberrations (CA) because both test detect partially similar endpoints (acentric chromosomes), so the non-increase in breaks seen in CA and the similar frequency of $M N$, before and after ozone therapy, is far from being eventual and refuses clastogenicity. It also indicates that ozone under these conditions do not affect the spindle fibers, an effect that has been already postulated [50]. It is concluded that ozone administered to patients by M-AHT, at a dose of $5 \mathrm{mg}$, do not present clastogenic effect.

\section{4.- Ozone by IP}

The results of the mutagenic effect of ozone by IP application, during 15 days in mice, is shown in Table 19. Even using a high ozone concentration of $70 \mu \mathrm{g} / \mathrm{mL}$, in doses that represent for IP (similar to M-AHT) increase of 2 to 10 times the maximum therapeutic dose, it is only present a slight cytotoxic and cytogenetic effect in the higher ozone doses.

It can be concluded that ozone had a cytotoxic effect at the highest dose $(2333 \mu \mathrm{g} / \mathrm{kg})$ when it is applied by IP route. Also, it presented a slight clastogenic activity at this dose and at $1633 \mu \mathrm{g} / \mathrm{kg}$. 
Table 19. Results of the mutagenic effect of ozone by IP application in mice, during 15 days.

\begin{tabular}{lccccccc}
\hline Doses & Cells & Mitotic index & Gaps & $\begin{array}{c}\text { Chromatidic break } \\
(\mathrm{CB})\end{array}$ & $\begin{array}{c}\text { Aberrants cells } \\
(\%)\end{array}$ & CB/cells & Gaps/cells \\
\hline Control $\left(\mathrm{O}_{2}\right) 1 \mathrm{~mL}$ & 200 & 0.015 & 2 & 3 & 1,5 & 0.015 & 0.010 \\
$\mathrm{O}_{3}(2333 \mu \mathrm{g} / \mathrm{kg})$ & 200 & $0.036^{*}$ & 6 & 11 & $5.5^{*}$ & $0.055^{*}$ & 0.033 \\
$\mathrm{O}_{3}(1633 \mu \mathrm{g} / \mathrm{kg})$ & 200 & 0.013 & 2 & 10 & $5.0^{*}$ & $0.050^{*}$ & 0.010 \\
$\mathrm{O}_{3}(933 \mu \mathrm{g} / \mathrm{kg})$ & 200 & 0.011 & 4 & 4 & 2.0 & 0.020 & 0.020 \\
$\mathrm{O}_{3}(466 \mu \mathrm{g} / \mathrm{kg})$. & 200 & 0.006 & 3 & 5 & 2.5 & 0.025 & 0.015 \\
\hline
\end{tabular}

Mitotic index-number of metaphases $x 1000$ cells. ${ }^{*} p<0.05$ (significant differences).

\section{4.- Teratogenic assay}

The results of the reproductive index, after the administration of 10 sessions of ozone by RI from the 6th to the 15th day of gestation, are shown in Table 20.

No toxic effect was observed in the pregnant rats submitted to the ozone treatment by RI. Mother weight gained did not show significant differences among the groups, neither the other indicators (number of corpus luteum, implantations, alive and dead fetus, reabsorptions). In respect to the fetus morphology, no external, skeletal or visceral malformations were observed. The weight and the length cranium-caudal did not show significant differences among the groups.

Metka et al [51] also obtained similar results when ozone is applied by intramuscular route at a dose of $150 \mu \mathrm{g}$. However, there are some studies that referred the presence of embryotoxic effects (no teratogenic effects)

Table 20. Reproductive index after the administration of ozone by RI to Wistar rats.

\begin{tabular}{lccc}
\hline Reproductive indexes & Control (without treatment) & $\mathrm{O}_{3}(150 \mu \mathrm{gg} / \mathrm{kg})$ & $\mathrm{O}_{3}(1600 \mu \mathrm{g} / \mathrm{kg})$ \\
\hline Number of mothers & 15 & 17 & 17 \\
Mother weight gained $(\mathrm{g})$ & $53.7 \pm 22.2$ & $54.0 \pm 24.5$ & $60.7 \pm 25.5$ \\
Corpus luteum/mother & $10.5 \pm 2.8$ & $10.8 \pm 1.7$ & $10.8 \pm 1.5$ \\
Implantations/mother & $9.1 \pm 2.5$ & $8.8 \pm 3.6$ & $9.9 \pm 1.6$ \\
Alive fetus/mother & $8.9 \pm 2.7$ & $8.6 \pm 3.6$ & $9.4 \pm 1.8$ \\
Reabsorptions/mother & $0.1 \pm 0.4$ & $0.2 \pm 0.5$ & $0.6 \pm 1.7$ \\
NR/MR & $2 / 2$ & $3 / 2$ & $10 / 2$ \\
Fetus weight (g) & $2.50 \pm 0.36$ & $2.70 \pm 0.44$ & $2.50 \pm 0.53$ \\
Fetus heighta $(\mathrm{cm})$ & $3.10 \pm 0.32$ & $3.10 \pm 0.23$ & $3.10 \pm 0.30$ \\
Preimplantation loss & $0.12 \pm 0.14$ & $0.20 \pm 0.31$ & $0.08 \pm 0.08$ \\
Postimplantation lossc & $0.03 \pm 0.09$ & $0.02 \pm 0.06$ & $0.05 \pm 0.13$
\end{tabular}

NR/MR-number of reabsorptions/mother with reabsorptions. aLength cranium-caudal. ${ }^{b}$ Difference between the number of corpus luteum and implantations/corpus luteum. 'Difference between the number of implantations and alive fetus/implantations. 
when the rats were exposed continuously to ozone by airway, at concentrations higher than $1.26 \mathrm{ppm}$, during several days [52,53]. It is important to highlight that this toxic effect is only obtained when ozone is inhaled. There is no doubt that prolonged ozone exposure by inhalation damages the respiratory system and extrapulmonary organs. Ozone, by reacting with the vast expanse of the bronchoalveolar space minimally protected by natural antioxidant defences, induces a huge formation of proinflammatory cytokines, reactive oxygen species and toxic lipid oxidation products. These products first initiate and perpetuate a local chronic inflammation and second, after absorption, reach and damage vital organs [54]. It is good to clarify that ozone can be toxic but, when properly used, can be medically useful.

\section{Conclusions}

The versatility of ozone applications is impressive and today ozone therapy can be performed using several different modalities. Some Nations in the world still do not allow the practice of ozone therapy either for ignorance, not enough preclinical and clinical trials, negligence, prejudice or because it is not performed correctly.

These toxicological studies that are presented here support the safety and innocuity of this therapeutic method. For the ozone rectal insufflation, the acute and subchronic toxicity studies demonstrated that there is no doseresponse effect in the blood parameters analyzed, nor histological damage at the macroscopic and microscopic level in any of the structures analyzed. Ozone dissolves into the rectal mucus and produce lipid oxidation products that are adsorbed by the rectal cells and go to the blood system, without provoking tissue damages, therefore, no systemic toxicity was observed. In addition, ozone is not a rectal irritant after its application in repeated doses, nor does it have mutagenic or teratogenic effects, in the dose levels applied. All these toxicological studies performed for the ozone rectal insufflation fulfilled the requirements established to implement an official registry.

Despite the presently compelling evidence, additionally toxicological studies (for example subchronic in two different animal species and teratogenic assays using different doses of ozone) must be performed to fulfil all the requirements for major autohemotherapy and intraperitoneal applications in order to prove the complete safety of these ways of ozone administration.

\section{References}

1. Razumovskii SD, Zaikov GE. Ozone and its reaction with organic compounds. Moscow (RU): Nauka; 1974.

2. Pryor WA. Ozone in all its reactive splendor. J Lab Clin Med. 1993;122:483-486.

3. Bocci V. Is it true that ozone is always toxic? The end of a dogma. Toxicol Appl Pharm. 2006;216:493-504.

4. Viebahn R. The use of ozone in Medicine. 3rd English ed. Iffezheim (DE): ODREI-Publishers; 1999.

5. Mattassi R. Ozonoterapia. Milano (IT): Organizzazione Editoriale Medico Farmaceutico; 1985.

6. Aubourg P. L'ozone medical: Production, posologie, modes d'applications cliniques. Bull Med Soc Med Paris. 1938;52:745-749.

7. Menendez S, Leon OS, Fernandez JL, Copello M, Weiser MT. Advances 
of Ozone Therapy in Medicine and Dentistry. La Havana (CU): Palacio de las Convenciones; 2016. 513 p. ISBN: 978069278138859999.

8. Victorin K. Review of genotoxicity of ozone. Mutat Res. 1992;277:221-238.

9. Wright DT. Ozone stimulates release of platelet activating factor and activates phospholipases in guinea pig tracheal epithelial cells in primary culture. Toxicol Appl Pharm. 1994;127:27-35.

10. McBride DE, Koenig JQ. Inflammatory effects of ozone in the upper airways of subjects with asthma. Am J Respir Crit Care Med. 1994;149:1192-1197.

11. Devlin RB, Folinsbee L, Biscardi F, Hatch G, Becker S. Inflammation and cell damage induced by repeated exposures of humans to ozone. Inhal Toxicol. 1997;9:211-235.

12. Harkema JR, Plopper CG, Hyde DM, St George JA. Response of macaque bronchiolar epithelium to ambient concentration of ozone. Am J Pathol. 1993;143:857-866.

13. Re L. Molecular Aspects and New Biochemical Pathways Underlying Ozone Effects. Clin Exp Pharmacol. 2018;8:248-252.

14. Centro de Toxicología Experimental (CETEX). Codigo de las buenas practicas de laboratorio. La Havana (CU): Centro nacional para la produccion de animales de laboratorio (CENPALAB); 1992.

15. Ministerio de Salud Publica. Codigo de las buenas practicas de laboratorio. Resolución 152 del 17 de septiembre de 1992. La Havana (CU): Ministerio de Salud Publica; 1992.

16. Fox JG, Cohen BJ, Loew FM. Laboratory animal medicine. Chapter 4. Biology and diseases of rats. ACLAM Series. Orlando (FL): Academic Press; 1984.

17. Nelson $\mathrm{H}$, Hayes $\mathrm{R}$. Short term repeated dosing and subchronic toxicity studies. In: Hayes W. Principles and Methods of Toxicology. 3rd ed. New York (NY): Raven Press; 1994. p. 649-762.

18. ECETOC. Recommendations for the harmonization of international guidelines for toxicity studies. Monograph 7. ECETOC: Brussels (BE); 1985.

19. OECD. Test No. 407: Repeated dose 28-day oral toxicity study in rodents. OECD Guidelines for the testing of chemicals. Section 4. Paris (FR): OECD Publishing; 2008. Available from: https://doi.org/ 10.1787/9789264070684-en.

20. International Organization for Standardization (ISO). Biological evaluation of medical devices - Part 10: Tests for irritation and sensitization (ISO 10993-10). Geneva $(\mathrm{CH})$ : International Organization for Standardization (ISO); 1995.

21. FDA. International conference on harmonisation. Guidance on specific aspects of regulatory genotoxicity tests for pharmaceuticals. Fed Register. 1996;61(80):18197-18202.

22. OECD. Guidelines for the testing of chemicals. In vivo mammalian bone marrow cytogenetic test-chromosomal analysis (475). Paris (FR): OECD Publishing; 1993.

23. Kirkland DL. Genetic toxicology testing requirements: Official and unofficial views from Europe. Environ Mol Mutagen. 1993;21(1):8-14.

24. Aeschbscher HU. Rates of micronuclei induction in different mouse strains. Mutat Res. 1986;164:109-115.

25. Heddle J, Hite $M$, Salamone $M$. The induction of micronucleus, a 
measure of genotoxicity. Mutat Res. 1983;123:61-118.

26. Hart Y, Hartley A. Induction of micronucleus in the mouse. Mutat Res. 1983;120:127-132.

27. Singh NP, McCoy MT, Tice RR, Schneider EL. A simple technique for quantification of low levels of DNA damage in individual cells. Exp Cell Res. 1988;175:184-191.

28. Tice RR. The single cell gel/comet assay: a microgel electrophoretic technique for the detection of DNA damage and repair in individual cells. In: Philips DH, Venitt S. Environmental mutagenesis. Oxford (UK): Bios Scientific Publishers Ltd; 1994.

29. Moorhead PS. Chromosome preparations of leukocytes cultured from human peripheral blood. Exp Cell Res. 1960;23:613-616.

30. Chebotarev AN. A modified method of differential sister chromatid exchanges staining. B Exp Biol Med. 1978;85:243-244.

31. Fenech M, Morley AA. Measurement of micronuclei in lymphocytes. Mutat Res. 1985;147:28-36.

32. Wilson JG. Embryological considerations in teratology. Teratology principles and techniques. Chicago (IL): University of Chicago Press; 1965.

33. Dawson $A B$. A note on the staining of the skeleton of cleared specimens with alizarin red stain. Stain Tech. 1926;1:123-124.

34. Briggs GB, Oehme W. Toxicology. In: Baker JH, Russell LJ. The laboratory rat. Research applications. Volume II, Chapter 5. American College of Laboratory Animal Series. Orlando (FL): Academic Press Inc; 1980.

35. Chinedu E, Arome D, Ameh FS. A New method for determining acute toxicity in animal models. Toxicol Int. 2013;20(3):224-226.

36. Matsuzawa T, Nomura M, Unno T. Clinical pathology reference ranges of laboratory animals. J Vet Med Sci. 1993;55(3):351-362.

37. Stevens K, Mylecaine L. Issues in chronic toxicology. In: Hayes W. Principles and methods of toxicology. 3th ed. New York (NY): Raven Press; 1984. p. 273-319.

38. Suber R. Clinical pathology methods for toxicological studies. In: Hayes W. Principles and methods of toxicology. 3th ed. New York (NY): Raven Press; 1984. p. 729-762.

39. Jeklova E, Leva L, Knotigova P, Faldyna M. Age-related changes in selected haematology parameters in rabbits. Res Vet Sci. 2009;86:525-528.

40. Alemán CL, Noa M, Más R, Rodeiro I, Mesa R, Menéndez R, et al. Reference data for the principal physiological indicators in three species of laboratory animals. Lab Animals. 2000;34:379-385.

41. Coles EH. Veterinary Clinical Pathology. 4th ed. Philadelphia (PA): WB Saunders; 1986. 486 p. ISBN: 9780721618289.

42. Murray RK, Granner PA, Mayer PA, Rodwell VW. Harper's Biochemistry. 25th ed. New York (NY): McGraw-Hill; 2000. 927 p. ISBN: 9780838536902.

43. Petruška $P$, Kalafová $A$, Kolesárová $A$, Zbyňovská $K$, Latacz $A$, Capcarová M. Effect of quercetin on haematological parameters of rabbits: a gender comparison. JMBFS. 2013;2(Special issue 1): 1540-1549.

44. Peterson ML, Smialowicz R, Harder S, Ketcham B, House D. The effect of controlled ozone exposure on human lymphocyte function. Environ 
Res. 1981;24:299-308.

45. Guyton AC, Hall JE. A textbook on medical physiology. 10th ed. Philadelphia (PA): W.B. Saunders Company; 2000. 1064 p. ISBN: 9780721686776.

46. Ganong WF. Review of medical physiology. 20th ed. New York (NY): McGraw Hill Lange; 2001. 870 p. ISBN: 9780838582824.

47. Díaz Llera S, González Y, Prieto EA, Azoy A. Genotoxic effect of ozone in human peripheral blood leukocytes. Mutat Res. 2002;517:13-20.

48. Duell TH, Lengfelder E, Fink R, Giesen R, Bauchinger M. Effect of activated oxygen species in human lymphocytes. Mutat Res. 1995;336:29-38.

49. Yu TW, Anserson D. Reactive oxygen species-induced DNA damage and its modification: a chemical investigation. Mutat Res. 1997;379:201-210.

50. Gyorgy SN, Young S. Sensitivity of pol A mutants of Escherichia coli k-12 to ozone and radiations. Mutagenesis. 1988;3(3):257-261.

51. Metka $M$, Enzelsberger $H$, Salzer $H$, Rokitansky A. Zur Frage der Teratogenität und Toxizität von medizinischem Ozon-ein Studie an trächtigen Ratten [On the issue of teratogenicity and toxicity of medical ozone-a study in pregnant rats]. OzoNachrichten. 1988;7:21-29.

52. Kavlock RJ, Daston G, Grabowski CT. Studies in the development toxicity of ozone: Prenatal effects. Toxicol Appl Pharmacol. 1979;48:19-28.

53. Kavlock RJ, Meyer E, Grabowski CT. Studies on the developmental toxicity of ozone: Postnatal effects. Toxicol Lett. 1980;5:3-9.

54. Bocci V. Tropospheric ozone toxicity vs. usefulness of ozone therapy. Arch Med Res. 2007;38:265-267. 